Redescription of Type Specimens of Species of the Bryozoan Genera Dekayia, Homotrypa, and Stigmatella from Upper Ordovician Rocks Along Workman's Creek, Ontario

Madeleine A. Fritz

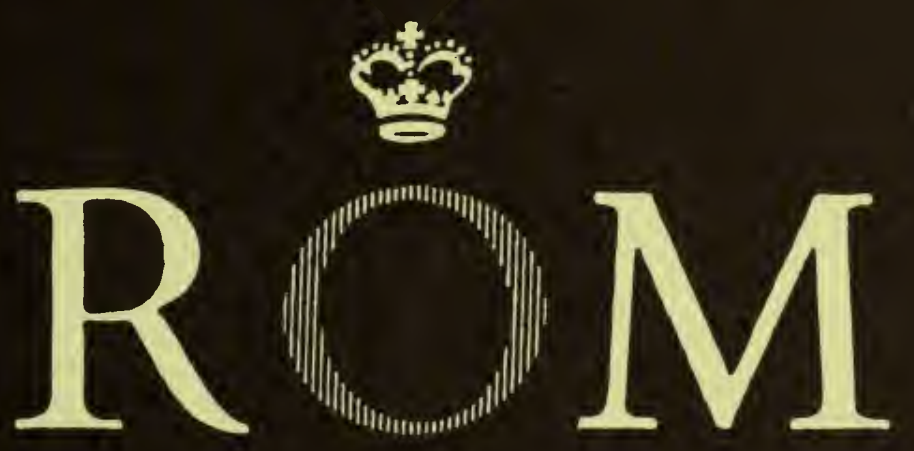




\section{ROYAL ONTARIO MUSEUM LIFE SCIENCES PUBLICATIONS INSTRUCTIONS TO AUTHORS}

Authors are to prepare their manuscripts carefully according to the following instructions. Failure to do so will result in the manuscript's being returned to the author for revision. All manuscripts are considered on the understanding that if accepted they will not be offered for publication elsewhere.

1. GENERAL Papers for publication are accepted from ROM staff members, Research Associates, or from researchers reporting on work done with ROM collections. In exceptional cases,monographic works on the flora and/or fauna of Ontario will be considered for publication by authors not affiliated with the ROM. Authors are expected to write clearly and concisely, and to omit all material not essential for an understanding of the main theme of the paper.

2. FORMAT Manuscripts are to be typed double-spaced (including captions, synonomies, literature cited, and tables) on 11 " $\times 8 \frac{1}{2}$ " " paper with a $1 \frac{112}{2}$ " margin on all sides. Three xerox copies are to be submitted to the Chairman of the Editorial Board, and the original retained by the author(s). A separate sheet is to be submitted giving author(s) names, affiliation, title of publication, series in which it is to appear, number of typed pages, number of tables, and number of figures. Manuscripts should normally be organized in the following order: Table of Contents, Abstract, Introduction, Materials and Methods, Results, Discussion, Conclusions, Summary (if paper is long), Acknowledgements, Literature Cited, and Appendices. Authors are encouraged to include foreign language translations of the Summary where appropriate. Headings of sections are to be left-justified to the text margin. The first line of the first paragraph in each new section should not be indented. Text-figures are referred to as "Fig. 1". Literature cited in the text is in the form "Jones (1972)" or "(Jones, 1972)" or "(Smith, 1960:71-79, fig. 17)".

3. STANDARD SOURCES The primary source for decisions on format and style is A Guide for Contributors and Editors of ROM Life Sciences Publications, available from the Chairman of the Editorial Board. Otherwise, consult CBE (AIBS) Style Manual (3rd Edition). Other standard sources are as follows: for English spelling (Concise Oxford Dictionary), for Canadian place names and coordinates (Gazetteer of Canada), and for spelling of geographic names (Times [London] Atlas).

4. ABSTRACT All papers are preceded by a short and factual abstract, about 3 per cent as long as the text, but not longer than 400 words. The abstract is to be followed by four to six keywords enclosed in brackets.

5. TAXONOMY The name of a taxon is given in full in headings, where it appears for the first time, or when the name begins a paragraph. Use authority and date if appropriate, with first mention of each taxon and not thereafter. Taxonomic papers follow the layout in Life Sciences Contribution 99, particularly the synonomies.

6. LITERATURE CITED References in the text cite author and date and are enclosed in parentheses (Smith, 1978). Complete references are listed in alphabetical order by author at the end of the paper. When there are two or more citations for an author, the works are listed chronologically. Names of joumals are not abbreviated. Consult Life Sciences Contributions beginning with 117 for correct bibliographic form.

7. TABLES All tables are numbered consecutively in arabic numerals in numerical order of their first mention in the text. Mark the appropriate text location of each table with a marginal notation. Each table is typed on a separate sheet. Avoid footnotes etc., to tables by building them into the title.

8. FIGURES All figures are numbered consecutively in arabic numerals. Component photographs or drawings are labelled sequentially in upper case letters. Mark the appropriate text location of each figure with a marginal notation. The intended reduction for figures is ideally one and a half to two times. All labelling on figures is in blue pencil and not inked or letraset. Halftones must be photographic prints of high contrast on glossy paper. Authors are to submit $10^{\prime \prime} \times 8$ " copies with the MS and retain originals until they are requested. Figure captions are to appear grouped together on a separate page at the end of the MS. 
MADeleine A. FRITZ Redescription of Type Specimens of Species of the Bryozoan Genera Dekayia, Homotrypa, and Stigmatella from Upper Ordovician Rocks Along Workman's Creek, Ontario 


\section{ROYAL ONTARIO MUSEUM PUBLICATIONS IN LIFE SCIENCES}

The Royal Ontario Museum publishes three series in the Life Sciences:

LIFE SCIENCES CONTRIBUTIONS, a numbered series of original scientific publications including monographic works.

LIFE SCIENCES OCCASIONAL PAPERS, a numbered series of original scientific publications, primarily short and usually of taxonomic significance.

LIFE SCIENCES MISCELLANEOUS PUBLICATIONS, an unnumbered series of publications of varied subject matter and format.

All manuscripts considered for publication are subject to the scrutiny and editorial policies of the Life Sciences Editorial Board, and to review by persons outside the Museum staff who are authorities in the particular field involved.

\section{LIFE SCIENCES EDITORIAL BOARD}

Senior Editor: C. McGOWAN

Editor: P.H. von BITTER

Editor: R. WINTERBOTTOM

MADELEINE A. FRITZ is Research Associate in the Department of Invertebrate Palaeontology, Royal Ontario Museum.

\section{Canadian Cataloguing in Publication Data}

Fritz, Madeleine A., date

Redescription of type specimens of species

of the Bryozoan genera Dekayia, Homotrypa, and Stigmatella

from Upper Ordovician rocks along Workman's Creek, Ontario

(Life sciences contributions, ISSN 0384-8159; no. 132)

Bibliography: $p$.

ISBN 0-88854-285-2

1. Bryozoa, Fossil. 2. Paleontology-Ordovician.

3. Paleontology—Ontario-Workman's Creek. I. Royal Ontario Museum.

II. Title. III. Series.

QE798.F74 564'.7'09713 C82-094055-0

Publication date: 19 January 1982

ISBN 0-88854-285-2

ISSN 0384-8159

(C) The Royal Ontario Museum, 1982

100 Queen's Park, Toronto, Canada M5S 2C6

PRINTED AND BOUND IN CANADA AT THE ALGER PRESS 


\title{
Redescription of Type Specimens of Species of the Bryozoan Genera Dekayia, Homotrypa, and Stigmatella from Upper Ordovician Rocks Along Workman's Creek, Ontario
}

\begin{abstract}
Bryozoan species described by the author in 1926 from the Upper Ordovician Georgian Bay (Meaford) Formation are redescribed both qualitatively and quantitatively. These types are housed in the Department of Invertebrate Palaeontology, Royal Ontario Museum.
\end{abstract}

\section{Introduction}

This publication is devoted to the redescription of bryozoan type specimens from the marine rocks outcropping along Workman's Creek, a small stream that enters Nottawasaga Bay approximately $4 \mathrm{~km}$ southeast of the town of Meaford, Grey County, Ontario. On 2 June 1945 Workman's Creek was renamed East Meaford Creek, but in 1976 the original name was restored by the Ontario Geographic Names Board.

The marine strata along Workman's Creek were correlated with those of the Toronto region (Parks, 1925a; Dyer, 1925). The stratigraphic sequence recognized by the author (1926) for the Workman's Creek Section is as follows:

$\begin{array}{ll}\text { Formation } & \text { Member } \\ \text { Meaford } & \text { Vincent } \\ & \text { Erindale }\end{array}$

$\begin{array}{ll} & \text { Christie } \\ \text { Dundas } & \text { Humber } \\ & \text { Danforth } \\ & \text { Rosedale }\end{array}$

Liberty (1969) included this section in the upper part of the Georgian Bay Formation. 


\section{Materials and Methods}

The primary types of the following species are treated in this paper:

Dekayia appressa distincta Fritz, ROM 1308HR, herein Dekayia distincta Fritz

Dekayia granulosa Fritz, ROM 1309HR

Dekayia meafordensis Fritz, ROM 1310HR

Homotrypa cincinnatiensis meafordensis Fritz, ROM 12317, herein Homotrypa meafordensis Fritz

Stigmatella sessilis delicatula Fritz, ROM 1316HR

Stigmatella intermedia Fritz, ROM 1276HR

Stigmatella crenulata meafordenis Fritz, ROM 1313HR

Stigmatella peculiaris Fritz, ROM 12318

Stigmatella vulgaris ramosa Fritz, ROM 1317HR

Stigmatella peculiaris similis Caley, ROM 1530HR, herein $S$. similis

In addition, two figured specimens of Stigmatella crenulata Ulrich and Bassler, USNM 43197 and 43198 , were kindly lent by the United States National Museum.

The external features of the zoaria, such as colony shape and surface character, were observed by hand lens, and the internal structures by thin sections. The mensuration of the number of zooecia in $2 \mathrm{~mm}$ in the intermonticular or intermacular areas and the measurements in millimetres of the maximum dimension of zooecial apertures in the monticular, macular, and "inter" areas were made with a binocular microscope and a micrometre scale calibrated to $0.01 \mathrm{~mm}$. The number of entire mesopores and the number of entire acanthopores in $1 \mathrm{~mm}^{2}$ were obtained by using a compound microscope and a reticle calibrated to $1 \mathrm{~mm}^{2}$. Statistical computations were made on the IBM360 computer at the University of Toronto Computer Centre. As most of the samples had heterogeneous variances, it was not possible to test differences among means using parametric statistical methods; instead the samples were tested for differences in dispersion using the non-parametric Mann-Whitney U-Test (Siegel, 1956). In the tables, probability ranges associated with the significance tests are designated with asterisks as follows: $* * *=P \leqslant 0.001 ; * *=P$ $\leqslant 0.01 ; *=P \leqslant 0.05$; not significant $=\mathrm{ns}=P>0.05$.

\section{Systematic Palaeontology}

Order Trepostomata Ulrich, 1882

Family Heterotrypidae Ulrich, 1890

Genus Dekayia Milne-Edwards and Haime, 1851

\section{Type Species}

Dekayia aspera Milne-Edwards and Haime, 1851 


\section{Dekayia distincta Fritz}

Fig. 1A-D

Dekayia appressa distincta Fritz, 1926: 98, 99.

\section{EXTERNAL FEATURES}

Type a single round branch, $20 \mathrm{~mm}$ long, $6 \mathrm{~mm}$ diameter, compressed with growth to $11 \mathrm{~mm}$ wide by $4 \mathrm{~mm}$ thick. Surface with small conical monticules, 2 to $3 \mathrm{~mm}$ apart centre to centre. Zooecia in monticules larger than those in intermonticular areas.

\section{TANGENTIAL SECTION}

Zooecia bluntly polygonal, 9 to 10.5 in $2 \mathrm{~mm}$ in intermonticular areas (Table 1); apertures oval, circular, subangular; walls appear amalgamate and concentrically laminated, mural lacunae prominent. Mesopores scarce (Table 1). Acanthopores moderately abundant (Table 1), 0.02 to $0.05 \mathrm{~mm}$ diameter, with walls concentrically laminated and central core clear. Diameter of zooecial apertures in monticules 0.17 to $0.25 \mathrm{~mm}$, in intermonticular areas 0.13 to $0.16 \mathrm{~mm}$ (Table 1).

\section{LONGITUDINAL SECTION}

Zooecia fanning out gradually, meeting zoarial surface perpendicularly to slightly obliquely. Endozone walls thin, undulating or finely crenulated throughout the several rejuvenations; crenulation coarser in terminal endozone. At base of exozone walls thicken gradually, becoming irregularly thickened as growth proceeds. Usually two diaphragms per zooecium in exozone. Mural lacunae show clearly in certain areas. Acanthopores not observed in endozone, but a few appear in exozone where they are short, relatively stout structures with cone-in-cone walls and clear central axis; some protruding beyond surface as low pointed cones.

\section{Remarks}

Dekayia distincta differs from Dekayia appressa in being uniformly larger and in having more numerous acanthopores, fewer diaphragms, irregular zooecial walls in exozone, and in lacking closely spaced diaphragms in mesopores of exozone. Quantitative data are not at present available for $D$. appressa. Howe ver, in Table $1 D$. distincta is shown in comparison with $D$. granulosa and $D$. meafordensis.

\section{Type}

Holotype: ROM 1308HR, Dundas Formation, Christie Member, Workman's Creek, Ontario. 

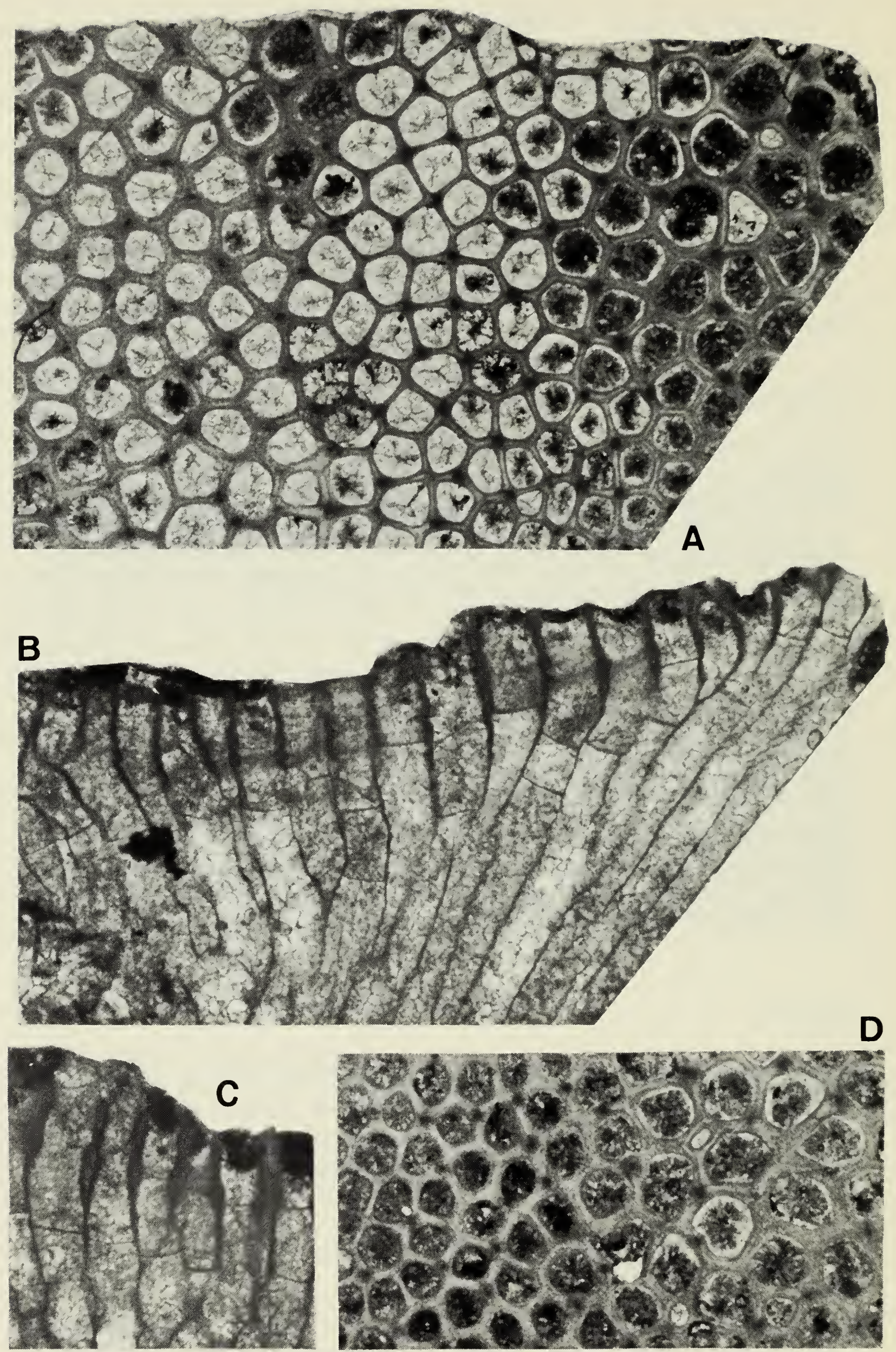

Fig. 1 A-D Dekayia distincta Fritz, holotype, ROM 1308HR

A, D Tangential section, $\times 30$

$B, C$ Longitudinal section, $\times 30$ 


\section{Dekayia granulosa Fritz, 1926}

Figs. 2A, B; 4F

Dekayia granulosa Fritz, 1926: 99.

\section{EXTERNAL FEATURES}

Type a Y-shaped fragment, $25 \mathrm{~mm}$ long; zoarium dichotomously branched with average branch diameter $5 \mathrm{~mm}$. Surface smooth, with maculae composed of zooecia larger than those in the intermacular areas.

\section{TANGENTIAL SECTION}

Zooecia subangular with apertures round, oval, or bluntly polygonal, 9 to 12 in $2 \mathrm{~mm}$ in intermacular areas (Table 1); walls 0.02 to $0.04 \mathrm{~m}$ wide, amalgamate, concentrically laminate, with clear central band highlighting junction of contiguous zooecia; walls with tiny lacunae. Mesopores rare (Table 1); acanthopores numerous (Table 1), mostly in zooecial angles very slightly inflecting the zooecial void, 0.02 to $0.03 \mathrm{~mm}$ in diameter, with walls concentrically laminated and clear central core. Maculae about $3 \mathrm{~mm}$ apart centre to centre, composed of larger zooecia surrounding small central cluster of mesopores. Diameter of zooecial apertures in maculae 0.15 to $0.20 \mathrm{~mm}$ (Table 1), in intermacular areas 0.13 to $0.16 \mathrm{~mm}$ (Table 1).

\section{LONGITUDINAL SECTION}

Zooecia bend abruptly to surface from outer endozone. Walls in endozone thin, undulatory to crenulate in successive growth stages, becoming coarsely crenulate prior to zooecial bend where one (rarely two) diaphragms occur; otherwise no diaphragms visible throughout endozone. In exozone, walls gradually thickening, becoming irregular to slightly moniliform. Diaphragms normally one, at zooecial bend, and one in exozone where two rejuvenations are recognized. Acanthopores not distinguishable in endozone, but visible in exozone where they are short and stout with cone-in-cone wall structure and clear central axis; at times merely the laminate walls are preserved; some project beyond the zoarial surface as short spines. Wall lacunae show clearly in certain locales.

\section{Remarks}

Dekayia granulosa might be mistaken for Dekayia meafordensis considered qualitatively, but internally the smaller zooecia and more numerous acanthopores help distinguish D. granulosa. D. maculata (James, 1881) is like D. granulosa except that maculae in the latter species are composed of groups of larger zooecia surrounding central clusters of small mesopores. Statistical analysis (Table 1) in which $D$. distincta, $D$. granulosa, and $D$. meafordensis are compared shows their relationship to one another when considered quantitatively. 


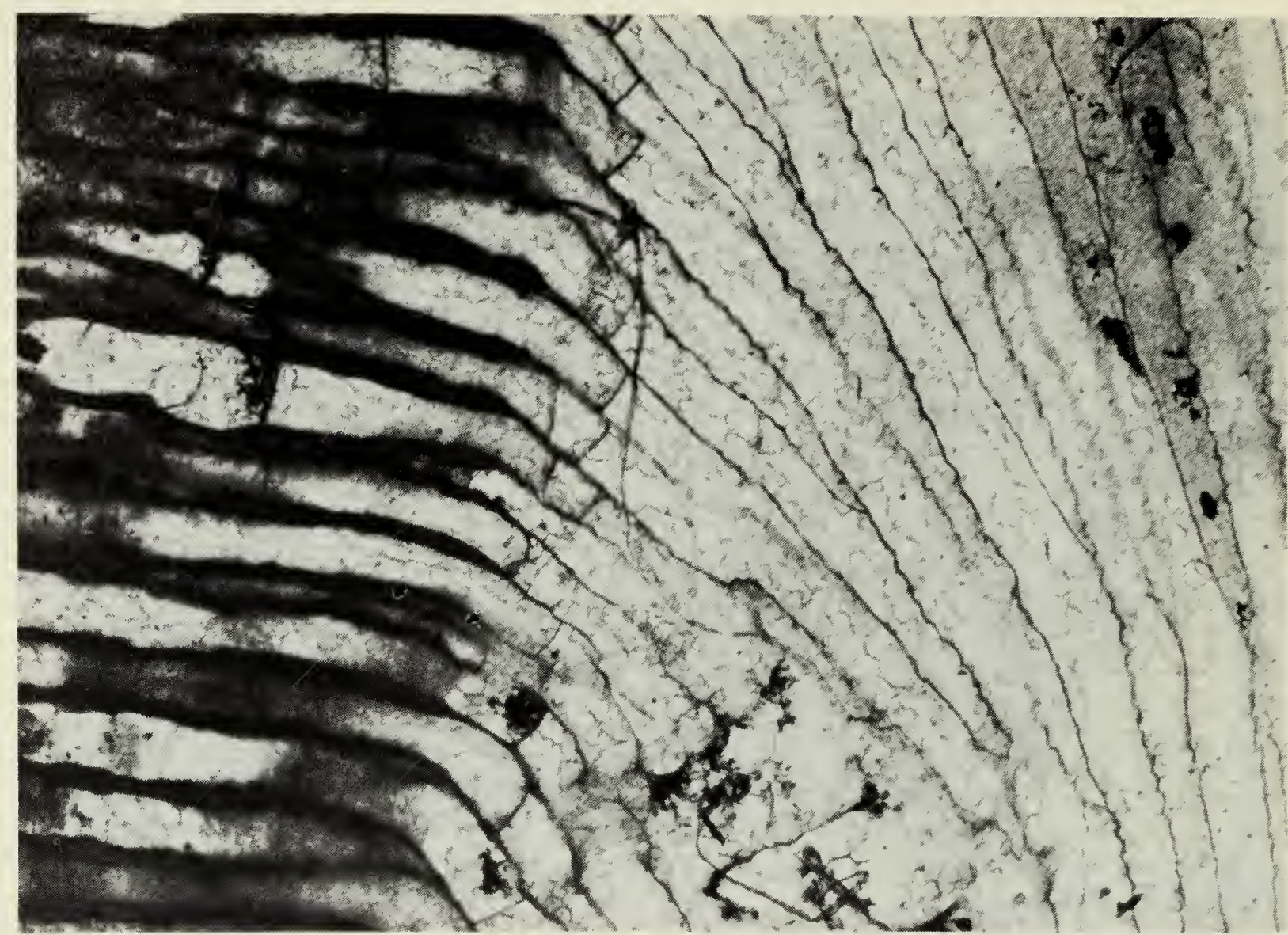

\section{A}

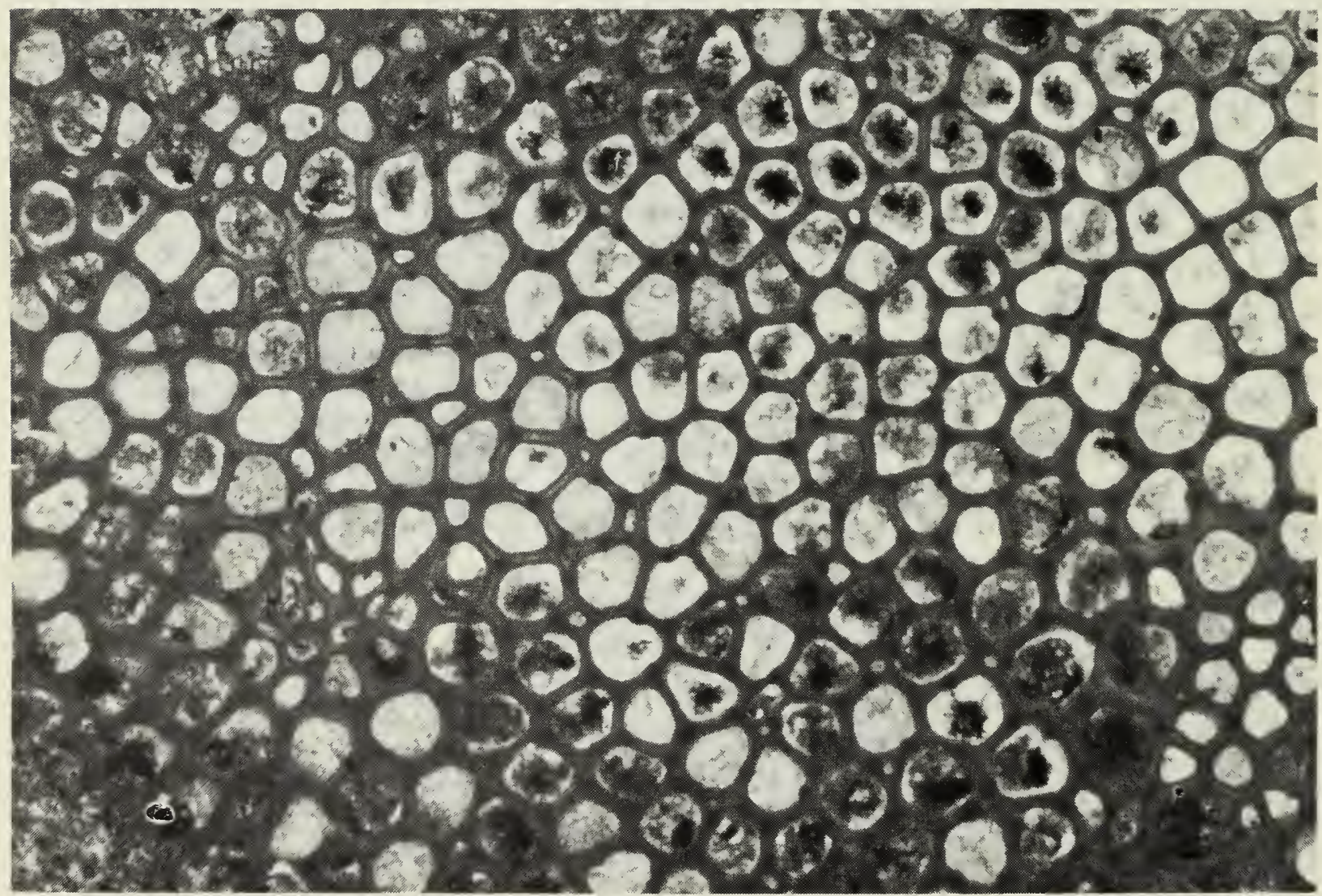

B

Fig. 2 A-B Dekayia granulosa Fritz, holotype, ROM 1309HR.

A Longitudinal section, $\times 30$

B Tangential section, $\times 30$ 
Holotype: ROM 1309HR, Dundas Formation, Christie Member, Workman's Creek, Ontario.

\section{Dekayia meafordenis Fritz, 1926}

Fig. 3A-D

Dekayia meafordensis Fritz, 1926: 100.

\section{EXTERNAL FEATURES}

Zoarium ramose, $\mathrm{Y}$-shaped, branching at 45-degree to 90-degree angle, diameter 4 to $7 \mathrm{~mm}$; surface smooth, but with maculae composed of larger zooecia than in the intermacular areas.

\section{TANGENTIAL SECTION}

Zooecia polygonal, apertures irregular in shape, 8 to 11 in intermacular areas (Table 1), walls 0.01 to $0.03 \mathrm{~mm}$ wide, concentrically laminated, apparently amalgamate, with clear central area highlighting contiguous zooecia (Table 1). Mesopores rare (Table 1), acanthopores numerous (Table 1), 0.03 to $0.04 \mathrm{~mm}$ diameter, with concentrically laminated walls and clear round centre. Mural lacunae distinct. Diameter of zooecial aperture in maculae 0.18 to $0.22 \mathrm{~mm}$ (Table 1), in intermacular areas 0.11 to $0.19 \mathrm{~mm}$ (Table 1 ).

\section{LONGITUDINAL SECTION}

Zooecial walls thin, undulating to crenulate in successive endozonal growths, and becoming more coarsely crenulate prior to the acute zooecial bend. Throughout endozone, one diaphragm per zooecium at termination of each rejuvenation; occasionally, a beadlike swelling represents a resorbed exozonal wall. Walls in relatively short exozone show two growth stages, each with irregular beaded walls, thicker as growth proceeds, and each growth stage with one diaphragm. Stout acanthopores with cone-in-cone wall structure and bright central axis, protruding beyond surface as appreciable spines. Mesopores very rarely present.

\section{Remarks}

The emended description of the genus Dekayia Boardman and Utgaard, 1966, typified by the species $D$. aspera Milne-Edwards and Haime, leaves little doubt that the Workman's Creek species are close variants of the genus as presently understood. Quantitatively, all three species belong to the group in which mesopores are almost absent; species are based upon shape of zoarium, presence of monticules or maculae, size of zooecia, character of walls, and number and character of acanthopores.

No quantitative data are available for $D$. aspera, but in Table $1 D$. distincta, $D$. granulosa, and $D$. meafordensis are compared quantitatively and the statistical relationships between the three species are indicated. 

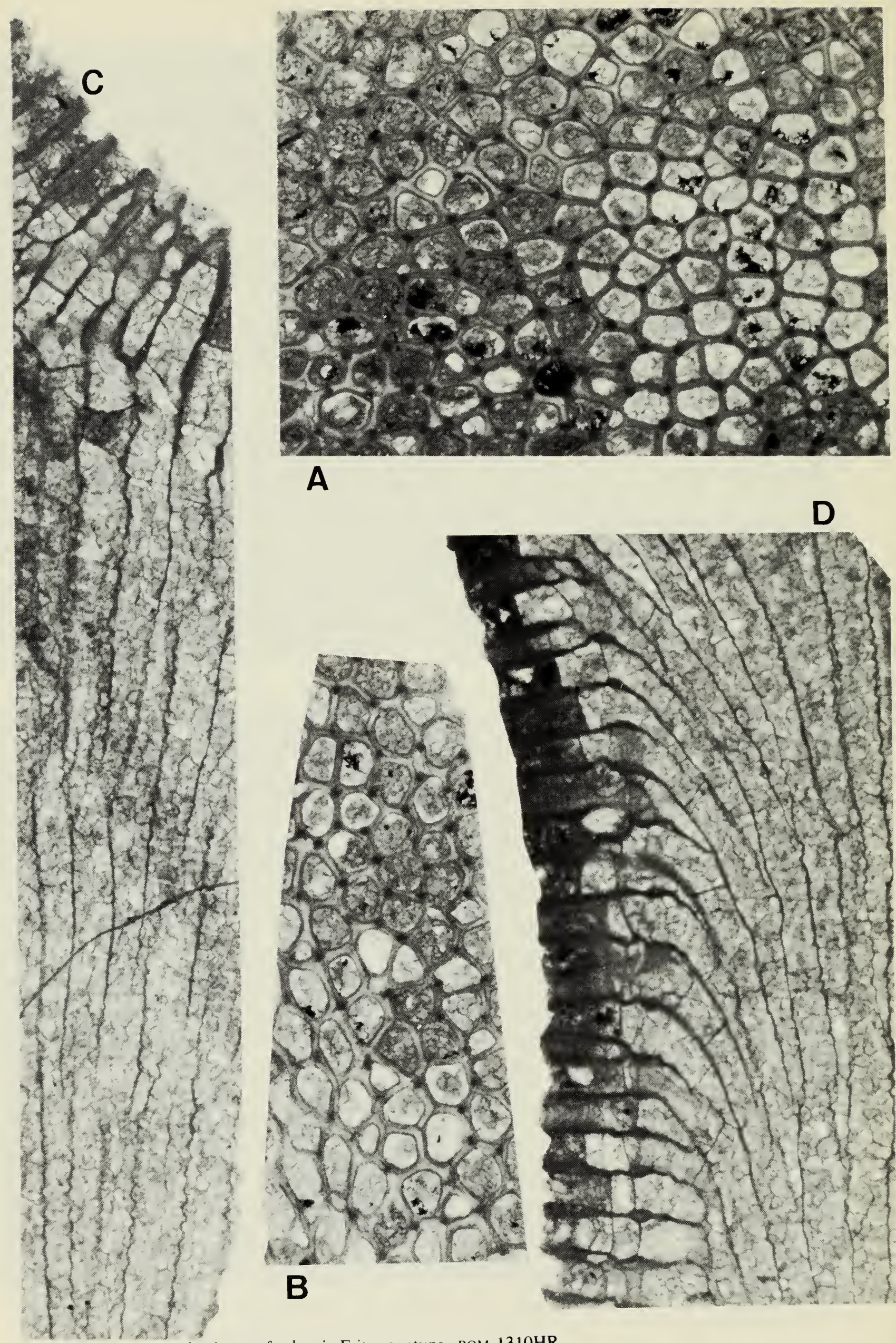

A

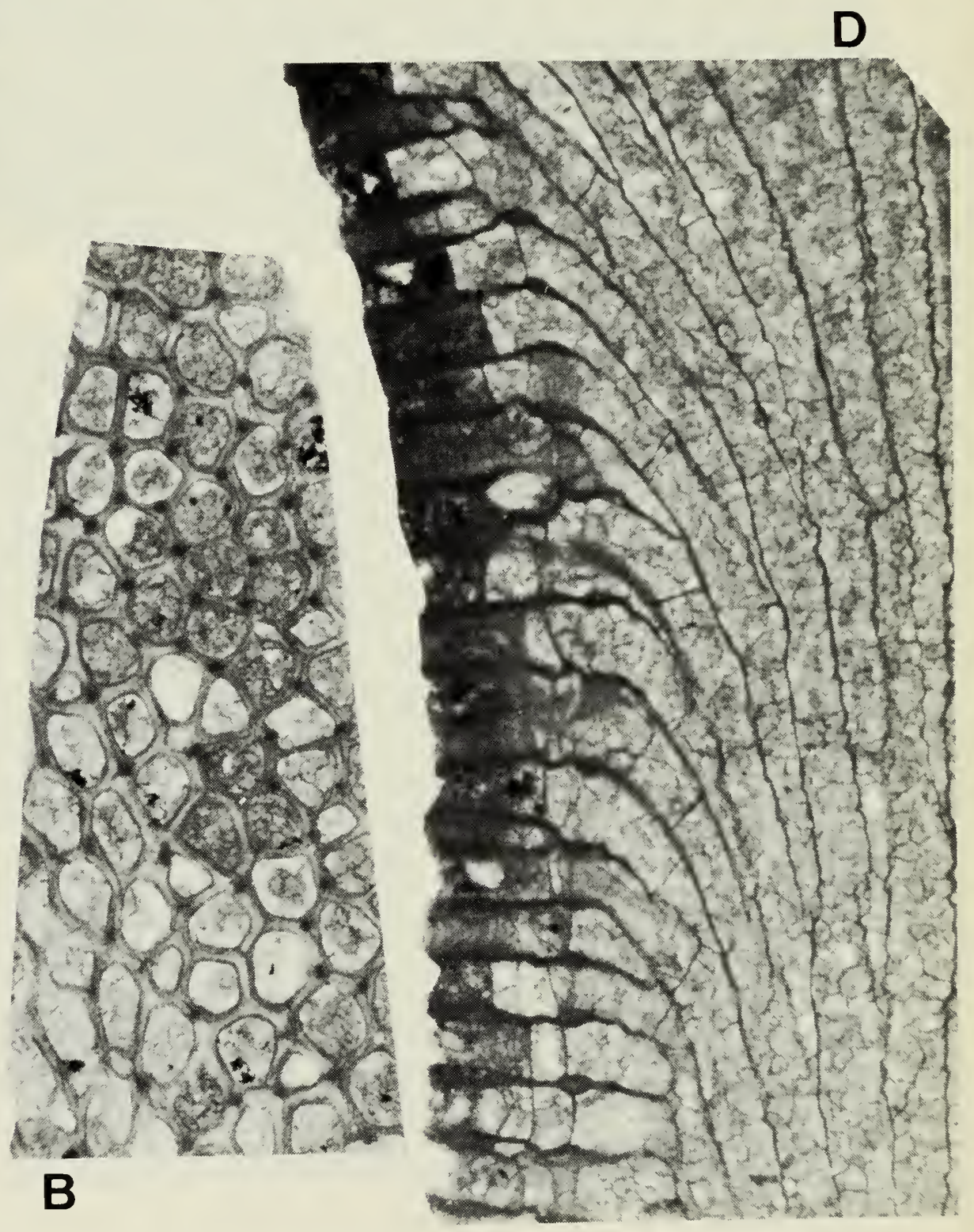

Fig. 3 A-D Dekayia meafordensis Fritz, syntype, ROM 1310HR.

A, B Tangential section, $\times 30$

C, D Longitudinal section, $\times 30$ 
Syntypes: ROM 1310HR, ROM 1327HR, Dundas Formation, Humber Member, Workman's Creek, Ontario.

Family Monticuliporidae Nicholson, 1881

Genus Homotrypa Ulrich, 1882

\section{Type Species}

Homotrypa curvata Ulrich, 1882.

\section{Homotrypa meafordenis Fritz}

Fig. 4A-E

Homotrypa cincinnatiensis meafordensis Fritz, 1926: 100.

\section{EXTERNAL FEATURES}

Zoarium ramose, consisting of an initial branch $10 \mathrm{~mm}$ in diameter from which arise dichotomously round branches 4 to $5 \mathrm{~mm}$ in diameter. Surface with small conical monticules 2 to $3 \mathrm{~mm}$ apart centre to centre; zooecia in monticules larger than those in the intermonticular areas.

\section{TANGENTIAL SECTION}

Zooecia round, oval, or bluntly polygonal 10 to 12 in $2 \mathrm{~mm}$ in intermonticular areas; walls concentrically laminated, 0.03 to $0.07 \mathrm{~mm}$ wide near surface, amalgamate with clear median zone (or in places with dark line interpreted as marking fusion of contiguous zooecia). Mesopores few (Table 2); acanthopores numerous (Table 2), at times slightly inflecting zooecial void, with walls concentrically laminated and clear central core. Maximum zooecial aperture in monticular area 0.20 to $0.27 \mathrm{~mm}$ (Table 2 ), in intermonticular area 0.12 to $0.18 \mathrm{~mm}$ (Table 2).

\section{LONGITUDINAL SECTION}

In each successive rejuvenation, walls first straight and wavy, followed by short zone of coarsely crenulated walls; at zooecial bend, walls become successively thicker with demarcation line distinct in exozone. Diaphragms straight and widely spaced in endozone; a few hook-shaped cystiphragms, at times overlapping, line distal wall in exozone. Mesopores with close-set diaphragms. Feather-shaped acanthopores, with steep laminae and clear central core, appear within zooecial wall or cutting across a zooecium; some protrude as blunt spines beyond zoarial surface. 


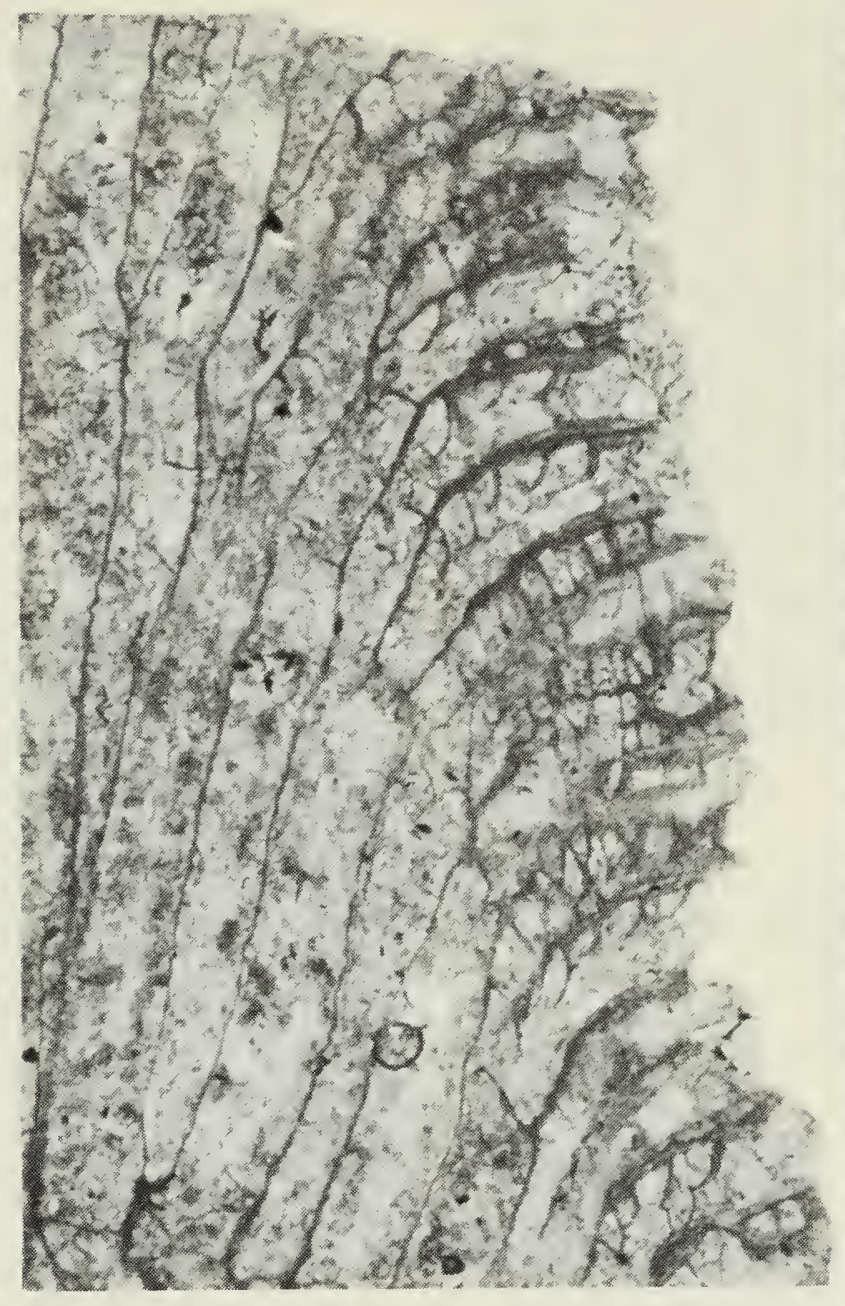

A

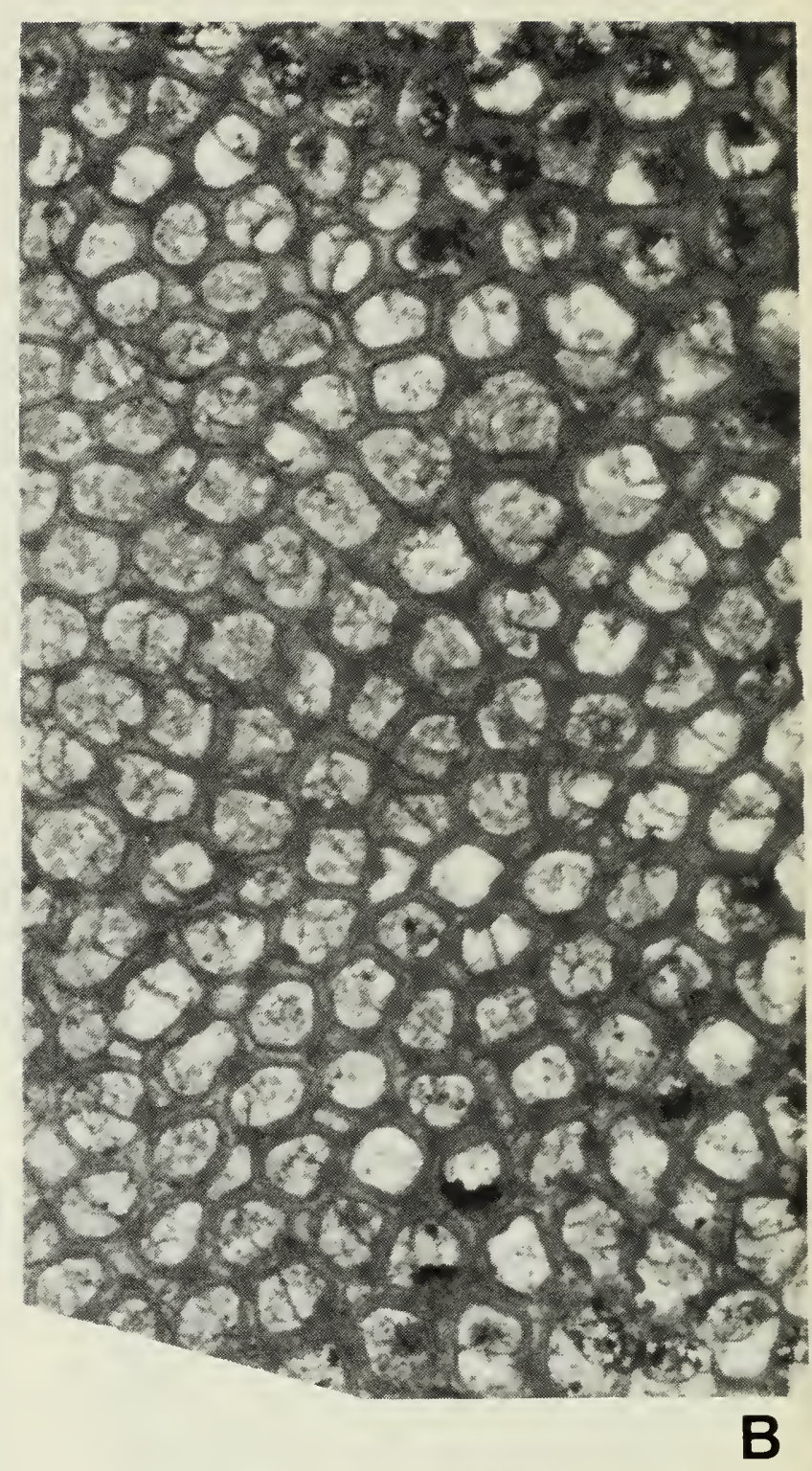

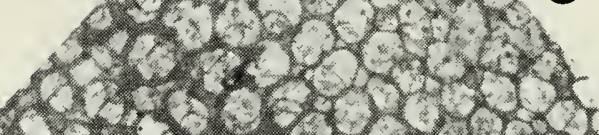

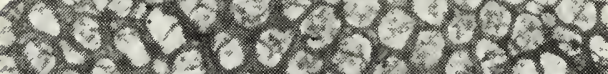

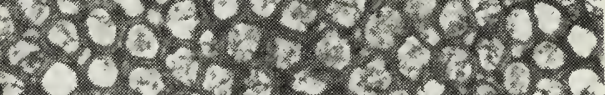

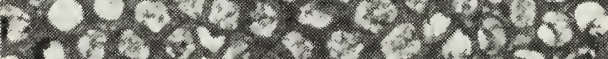

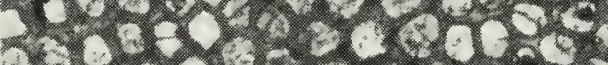

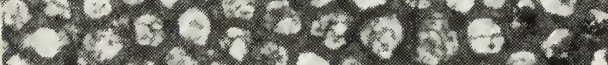

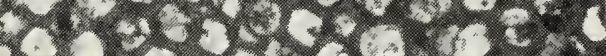

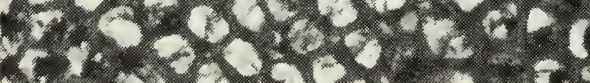

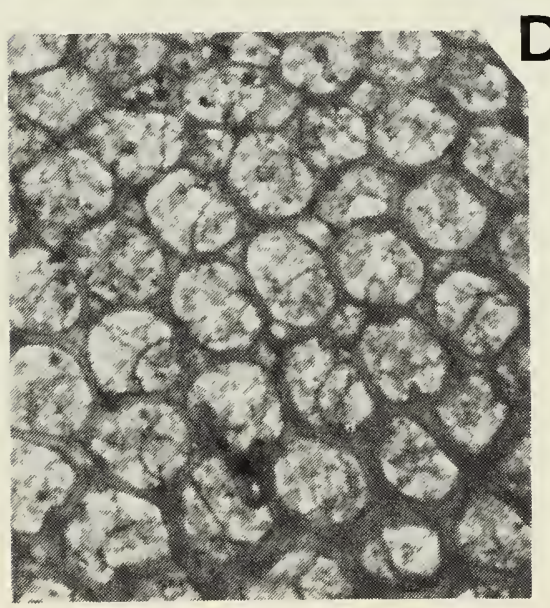

\section{C}
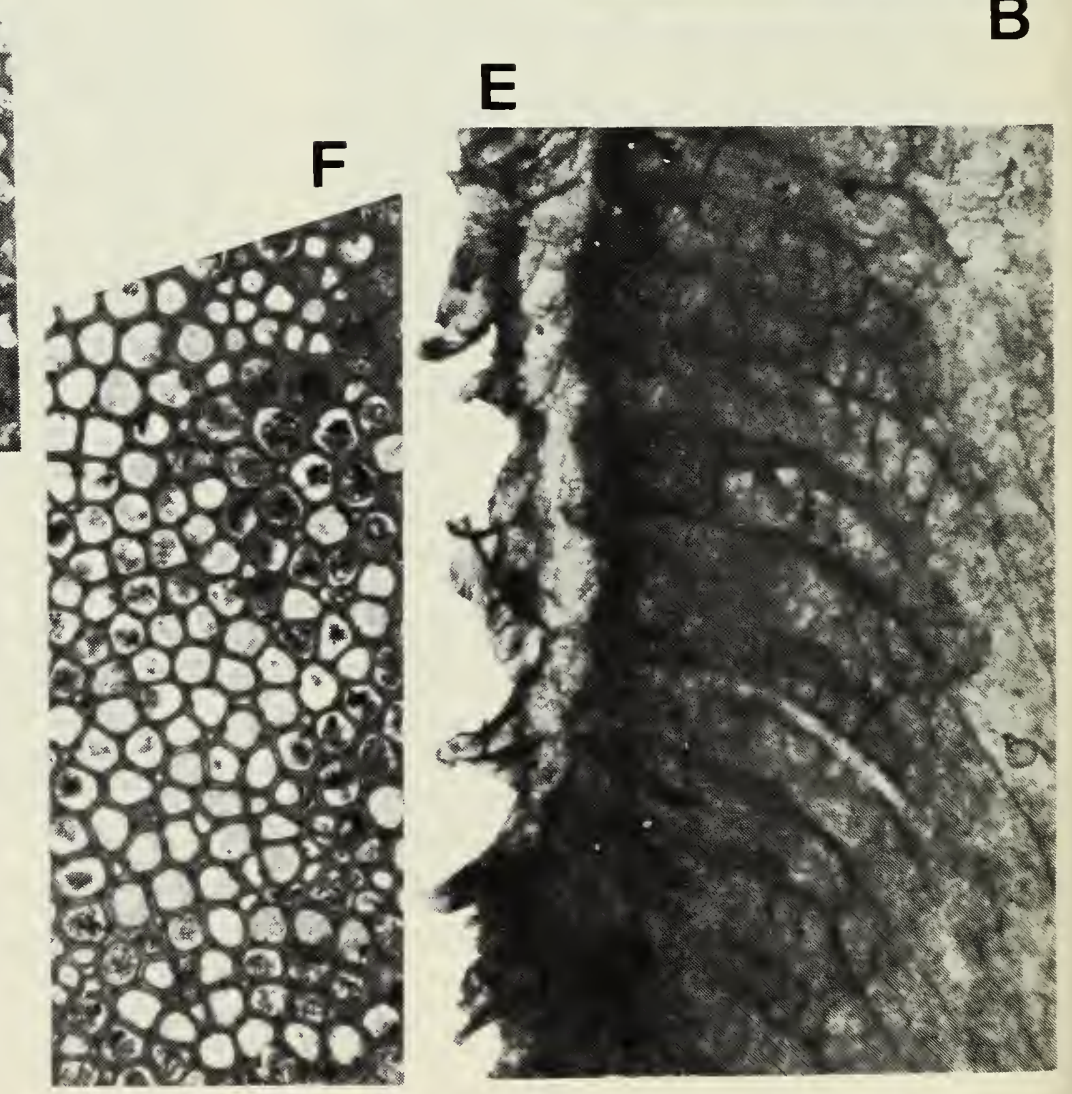


\section{Remarks}

On the basis of external features, Homotrypa meafordensis was originally considered a variety of Homotrypa cincinnatiensis (Bassler, 1903) from the Lorraine Formation of New York State. The present study has shown that a closer phenetic relationship exists between $H$. meafordensis and $H$. creditensis (Dyer, 1925; Fritz, 1977), each from the Upper Ordovician Meaford Formation. The two are alike in zoarium shape and monticuled surface, but when compared quantitatively (Table 2) they differ significantly in the number of mesopores and acanthopores in the intermonticular area, and the diameter of zooecia in the monticule and intermonticular area.

\section{Type}

Holotype: ROM 12317, Meaford Formation, Erindale Member, Workman's Creek, Ontario.

Family Heterotrypidae Ulrich, 1890

\section{Genus Stigmatella Ulrich and Bassler, 1904}

\section{Type Species}

Stigmatella crenulata Ulrich and Bassler, 1904.

\section{Stigmatella delicatula Fritz}

Fig. 5A-D

Stigmatella sessilis delicatula Fritz, 1926: 103.

\section{EXTERNAL FEATURES}

Zoarium an incrustation $1.5 \mathrm{~mm}$ thick (surrounding a pentagonal crinoid stem) from which extend small branches $7 \mathrm{~mm}$ long and $4 \mathrm{~mm}$ wide. Surface with small monticules spaced $1 \mathrm{~mm}$ apart centre to centre.

Fig. 4 A-E Homotrypa meafordensis Fritz, holotype, ROM 12317.

$A, E$ Longitudinal section, $\times 30$

B, D Tangential section, $\times 30$

C Tangential section, $\times 15$

F Dekayia granulosa Fritz, holotype, ROM 1309HR.

Tangential section, $\times 15$. 

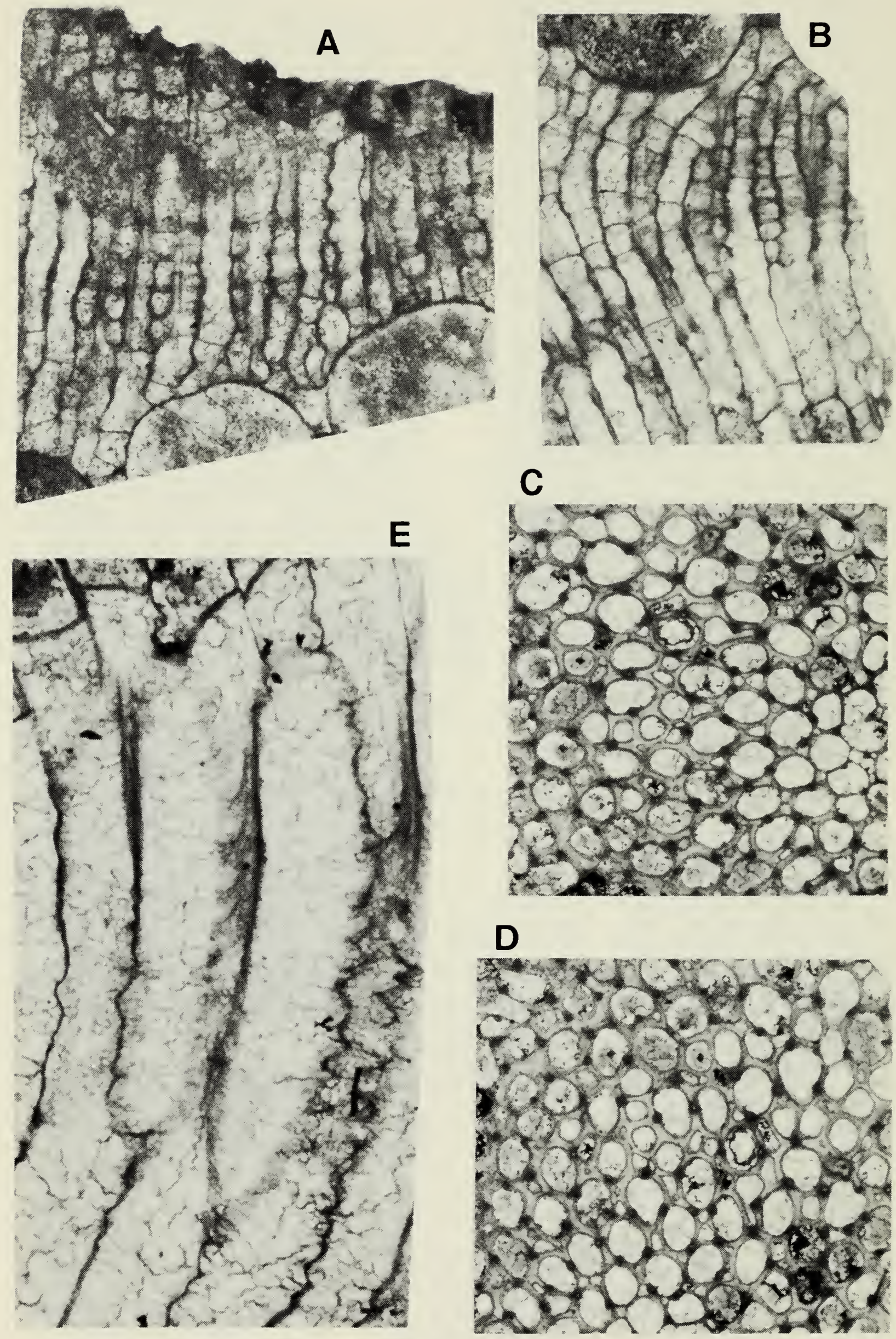

\section{C}
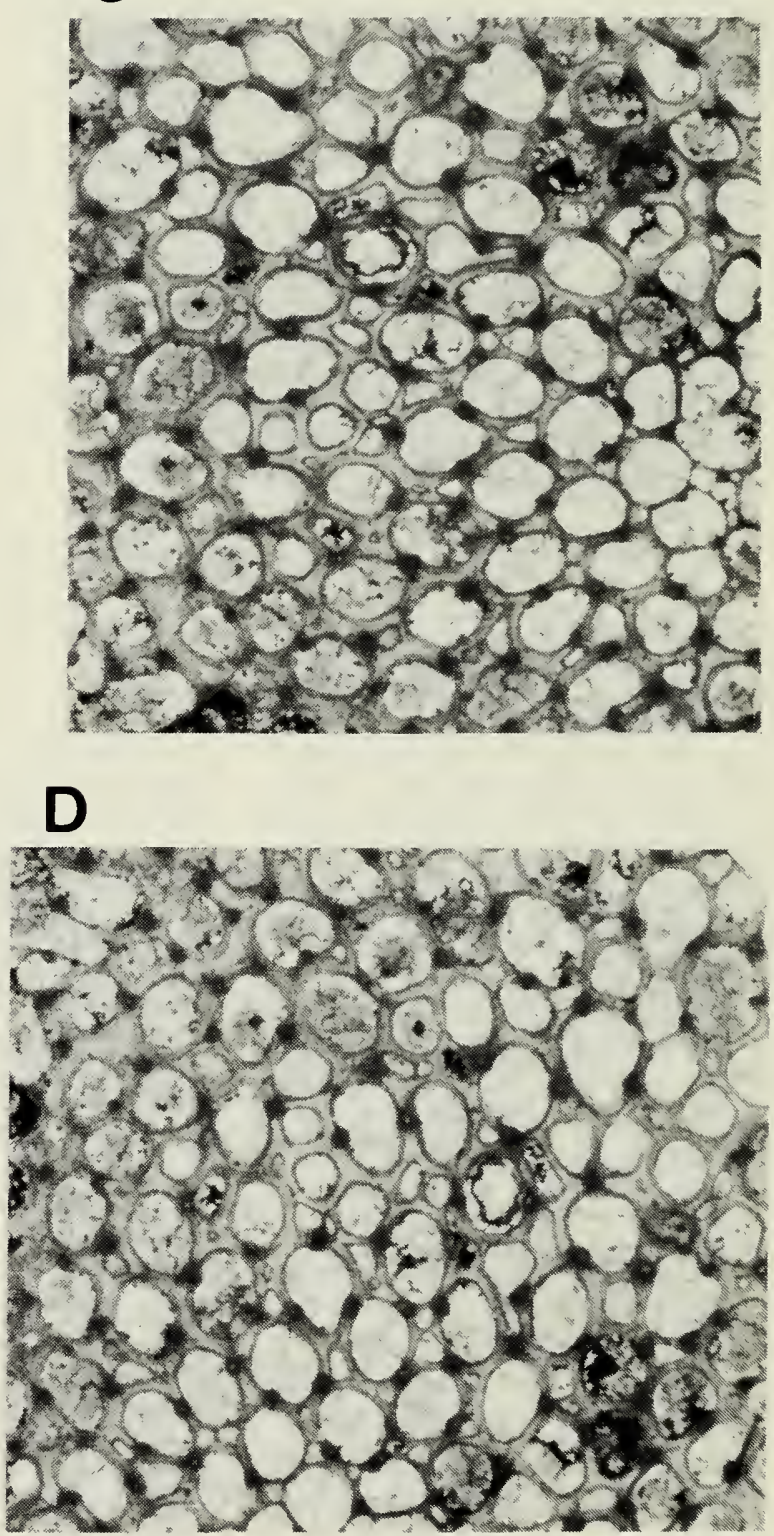
Zooecia oval to circular, a few slightly petaloid. Zooecia 8 to 12 in $2 \mathrm{~mm}$ in intermonticular area (Table 3); zooecial walls concentrically laminated, near surface up to $0.03 \mathrm{~mm}$ wide, gradually thinning at depth to $0.01 \mathrm{~mm}$; contiguous zooecia often showing dark line of demarcation. Mesopores few to relatively numerous (Table 3). Acanthopores abundant (Table 3), three to five surrounding each zooecium, in places slightly inflecting zooecial void; diameter 0.01 to $0.05 \mathrm{~mm}$; walls concentrically laminated, centre clear, round. Apertural diameter of zooecia in monticules 0.13 to $0.17 \mathrm{~mm}$ (Table 4), in intermonticular areas 0.10 to $0.13 \mathrm{~mm}$ (Table 3).

\section{LONGITUDINAL SECTION}

Zooecia briefly prostrate, then upright in long endozone in which several rejuvenations, separated by about $1 \mathrm{~mm}$, occur; walls in each at first thin and wavy, then crenulated and slightly thicker; two to three diaphragms in each growth stage. Zooecia turn outwards at angles of 45 degrees to 90 degrees; walls thicken gradually and become moniliform in short exozone, $0.05 \mathrm{~mm}$ long; wall laminae convex outwards, diverging at an angle of approximately 45 degrees, and passing into diaphragms, which are three to four per zooecium. Mesopores beadlike with at least five diaphragms spaced one tube diameter apart. Acanthopores with cone-in-cone structure and clear central core; protruding beyond surface as sharp spines, unless blunted by denudation.

\section{Remarks}

Stigmatella sessilis Cumings and Galloway (1913), of which the present species was considered to be a variety (Fritz, 1926), differs from $S$. delicatula in possessing adhesive monticuled discs, 10 zooecia in $2 \mathrm{~mm}$, and petaloid zooecial apertures, and in the absence of mesopores. Furthermore, $S$. sessilis is of Fairmount age and is therefore older. Among the species represented in the fauna under consideration, this taxon is unlike any species known to the author.

\section{Type}

Holotype: ROM 1316HR, Dundas Formation, Humber Member, Workman's Creek, Ontario.

Fig. 5 A-D Stigmatella delicatula Fritz, holotype, ROM 1316HR.

A Longitudinal section, $\times 30$

B Longitudinal section, $\times 30$

C Tangential section, $\times 30$

D Tangential section, $\times 30$

E Stigmatella meafordensis Fritz, holotype, ROM 1313HR Longitudinal section, $\times 60$ 


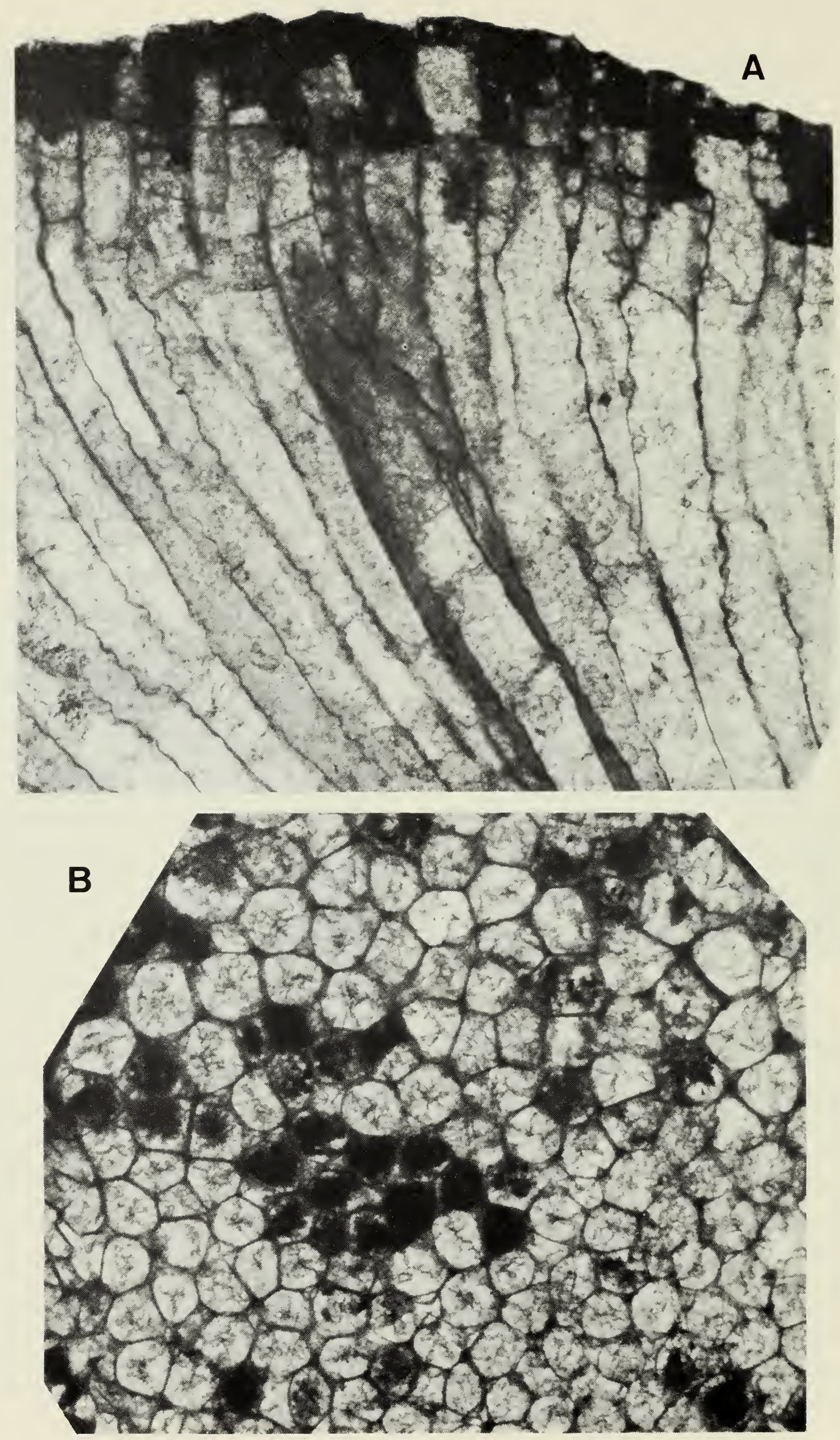




\section{Stigmatella intermedia Fritz, 1925}

Figs. 6A, B; 10

Stigmatella intermedia Fritz, in Parks, 1925b: 36.

Stigmatella intermedia Fritz, 1926: 103.

Although this species was mentioned and figured in 1925, it was not formally described until 1926.

\section{EXTERNAL FEATURES}

Zoarium a digitate growth which begins as a thin incrustation, $1 \mathrm{~mm}$ thick, on a round crinoid stem (Fritz, in Parks, 1925b: plate IV, fig. 1, misoriented). From the centre of the growth radiate four short, equally spaced, fingerlike projections, 10 to $12 \mathrm{~mm}$ in diameter and 5 to $6 \mathrm{~mm}$ long; these projections divide and redivide dichotomously diminishing in size and terminating in 16 small rounded processes each approximately $5 \mathrm{~mm}$ in diameter. Zoarial surface with small conical monticules spaced 2 to $3 \mathrm{~mm}$ apart centre to centre.

\section{TANGENTIAL SECTION}

Zooecia polygonal, 9 to 10.5 in $2 \mathrm{~mm}$ in area between monticules (Table 4); walls concentrically laminated, maximum thickness at surface $0.03 \mathrm{~mm}$, thicker in monticules. Mesopores few (Table 4). Acanthopores small, numerous (Table 4), noninflecting, situated in zooecial angles, $0.02 \mathrm{~mm}$ in diameter, walls concentrically laminated and clear round centre; maximum diameter of zooecia in monticular areas 0.20 to $0.28 \mathrm{~mm}$ (Table 4), in intermonticular areas 0.12 to $0.18 \mathrm{~mm}$ (Table 4).

\section{LONGITUDINAL SECTION}

Zooecia bending gradually from outer endozone, through short $(0.05 \mathrm{~mm}$ long) exozone, to surface, intersecting surface slightly obliquely. Endozone long, consisting of several rejuvenations, each approximately $1 \mathrm{~mm}$ long; walls tenuous, straight to wavy to crenulate; diaphragms seldom preserved, recrystallization having taken place. Acanthopores small, in zooecial angles, present in endozone, but structure not clear. Walls thickening gradually from outer endozone, becoming thicker, crenulate, and moniliform. Mesopores few, chainlike, with up to six diaphragms. Acanthopores with laminated walls, terminating beyond surface as low conical spines.

Fig. 6 A-B Stigmatella intermedia Fritz, holotype, ROM 1276HR.

A Longitudinal section, $\times 30$

B Tangential section, $\times 30$ 


\section{Remarks}

Stigmatella intermedia resembles $S$. crenulata more closely than $S$. catenulata, in that the numerous chainlike mesopores are absent. In order to compare $S$. intermedia with $S$. crenulata, thin sections from Ulrich's figured specimens (USNM 43197, 43198) were borrowed. These sections show that $S$. crenulata has conspicuously inflecting acanthopores resulting in distinctly petaloid zooecia apertures; furthermore, maculae composed of mesopores are present. Besides these morphological differences, $S$. crenulata is younger, being of Meaford (i.e., Waynesville stage) age. Table 4 indicates the statistical differences. The unique manner of growth of the colony, combined with the microstructure, distinguishes $S$. intermedia from other species.

\section{Type}

Holotype: ROM 1276HR, Dundas Formation, Humber Member, Workman's Creek, Ontario.

\section{Stigmatella meafordensis Fritz}

Figs. 5E; 7A-B

Stigmatella crenulata meafordensis Fritz, 1926: 71.

\section{EXTERNAL FEATURES}

Specimen a fragment $20 \mathrm{~mm} \times 35 \mathrm{~mm}$ from a lobate zoarium. Surface with low monticules; zooecia larger in monticules than between.

\section{TANGENTIAL SECTION}

Zooecia angular, 8 to 9 in $2 \mathrm{~mm}$ in intermonticular area (Table 5). Walls thin, 0.01 to $0.03 \mathrm{~mm}$ near surface. Mesopores few (Table 5). Acanthopores with clear round centre and concentrically laminated walls located in practically every zooecial angle, 0.01 to $0.025 \mathrm{~mm}$ diameter; maximum apertural diameter in monticules 0.27 to $0.35 \mathrm{~mm}$ (Table 5), in intermonticular areas 0.15 to $0.20 \mathrm{~mm}$ (Table 5).

\section{LONGITUDINAL SECTION}

Zooecia curving broadly to the surface, several rejuvenations each approximately 1 to $1.5 \mathrm{~mm}$ long apparent in the long exozone. Walls very thin and straight, becoming finely crenulate; usually two diaphragms per zooecium. Acanthopores randomly situated in the walls, tapering and needlelike with highly inclined laminate walls and clear round centre; extending beyond surface as sharp spines. Zooecial walls in the short exozone $(0.05 \mathrm{~mm}$ long), greatly thickened and crenulate, but non-moniliform. Mesopores few and beadlike. 


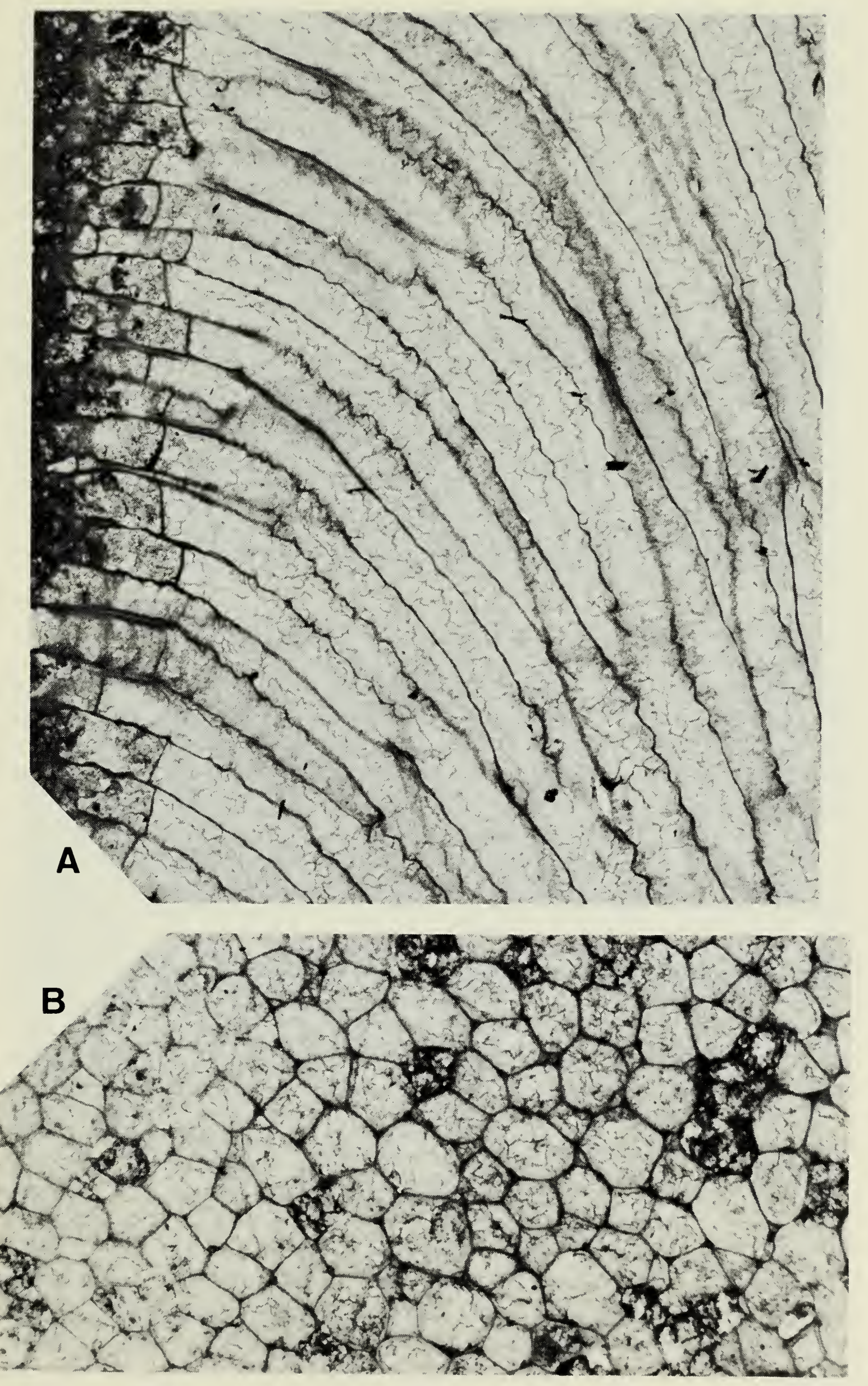

Fig. 7 A-B Stigmatella meafordensis Fritz, holotype, ROM 1313HR.

A Longitudinal section, $\times 30$

B Tangential section, $\times 30$ 


\section{Remarks}

Stigmatella meafordensis appears to be closest to $S$. vulgaris Parks and Dyer (1922). Qualitatively, the most significant difference is the large size of the zooecial aperture in both the monticular and intermonticular areas in the former. Data from the holotype of $S$. vulgaris (Fritz, 1973) and that of the present species are compared statistically in Table 5 .

\section{Type}

Holotype: ROM 1313HR, Dundas Formation, Humber Member, Workman's Creek, Ontario.

\section{Stigmatella peculiaris Fritz, 1926}

Fig. 8A-B

Stigmatella peculiaris Fritz, 1926: 104.

\section{EXTERNAL FEATURES}

Specimen consisting of one fragmentary branch, $20 \mathrm{~mm}$ long, $10 \mathrm{~mm}$ wide, showing bases of three small branches (diameter 3-8 mm). Surface with low bun-shaped monticules, approximately $2 \mathrm{~mm}$ in diameter at base, $1 \mathrm{~mm}$ in height, and spaced about $2.5 \mathrm{~mm}$ apart centre to centre; these monticules give surface a significant hummocky appearance.

\section{TANGENTIAL SECTION}

Zooecia polygonal, or irregular size, 9 to 13 in $2 \mathrm{~mm}$ in intermonticular areas (Table 6); apertures subangular to oval. Zooecial walls appear amalgamate (likely owing to recrystallization), but in places line of demarcation between walls is clearly defined. Amalgamated walls 0.03 to $0.04 \mathrm{~mm}$ wide in intermonticular areas, 0.06 to $0.07 \mathrm{~mm}$ wide in monticular areas. Mesopores virtually absent (Table 6). Acanthopores numerous (Table 6). Diameter of zooecial apertures in monticules 0.18 to $0.25 \mathrm{~mm}$, in intermonticular areas 0.14 to $0.17 \mathrm{~mm}$ (Table 6).

\section{LONGITUDINAL SECTION}

Endozone long, composed of several stages of colonial growth with zooecial walls at first straight or undulatory, then relatively coarsely crenulated. At regular intervals, monilae (traceable horizontally across section) represent resorbed exozonal stages. Diaphragms rare in endozone growths (each $1 \mathrm{~mm}$ in length). Zooecia curving gradually into short exozone (approximately $1 \mathrm{~mm}$ long); walls thickening, becoming somewhat moniliform; diaphragms commonly four per zooecium, spaced one tube diameter apart. Mesopores few, slightly chainlike, usually each with four diaphragms. Acanthopores obscured by thickness of the section, but a close examination of the external surface indicates that they extend beyond the surface as blunt projections. 

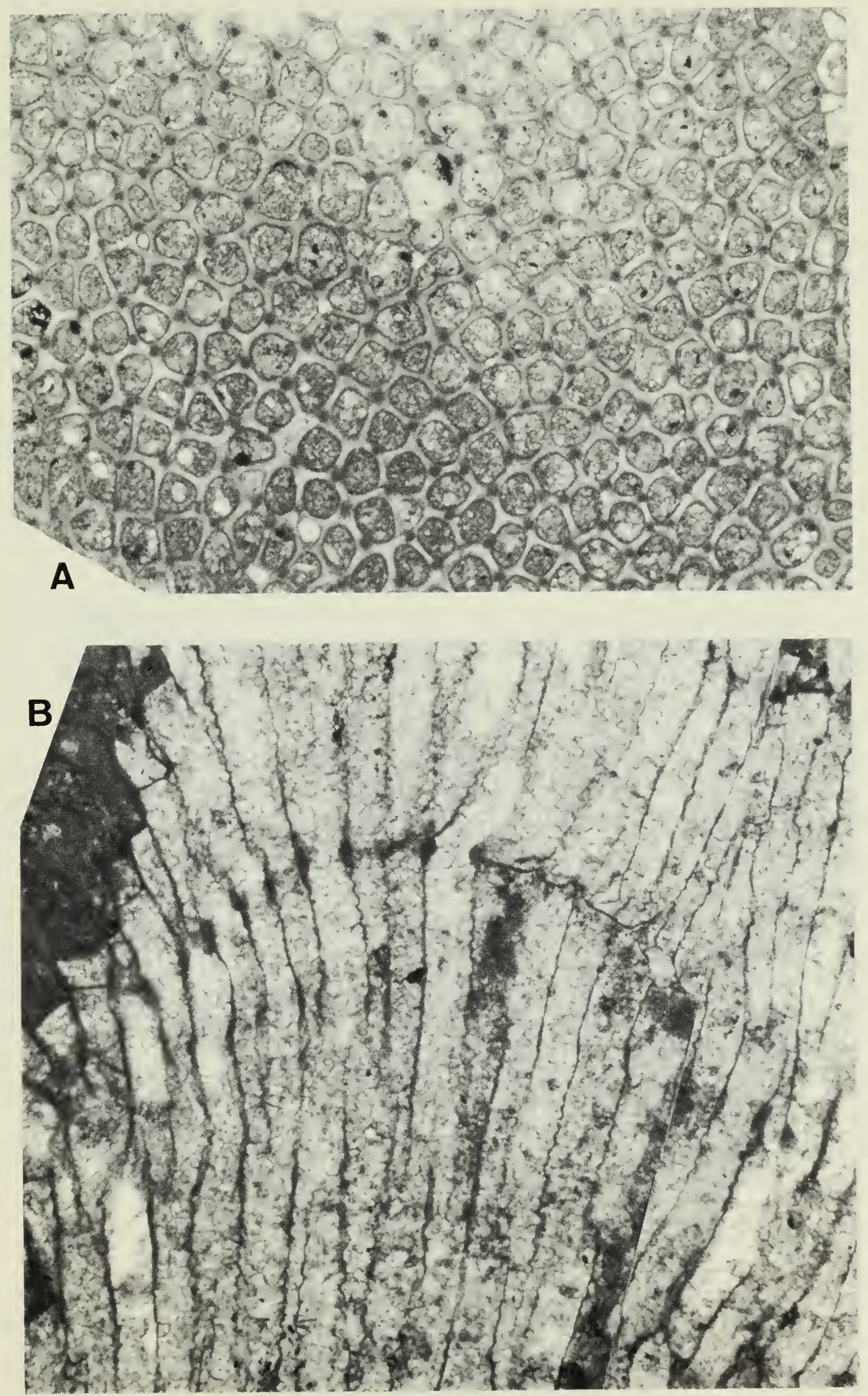

Fig. 8 A-B Stigmatella peculiaris Fritz, holotype, ROM 12318.

A Tangential section, $\times 30$

B Longitudinal section, $\times 30$ 


\section{Remarks}

Stigmatella similis Caley (1936; ROM 1530HR), from the Wekwemikongsing Formation of Manitoulin Island resembles $S$. peculiaris in the ramose zoarium with branches 5 to $10 \mathrm{~mm}$ in diameter. Zooecia, howe ver, are larger, numbering 8 to 10 in $2 \mathrm{~mm}$, and acanthopores are more numerous. Furthermore, the zoarial surface of Caley's variety is smooth, whereas that of the Meaford species is undulatory owing to the relatively large, closely spaced, bun-shaped monticules. Table 6 shows the quantitative comparison indicating a significant difference between the two.

\section{Type}

Holotype: ROM 12318, Meaford Formation, Vincent Member, Workman's Creek, Ontario.

\section{Stigmatella ramosa Fritz}

Fig. 9A, B

Stigmatella vulgaris ramosa Fritz, 1926: 105.

\section{EXTERNAL FEATURES}

Fragment $25 \mathrm{~mm}$ long, from a dichotomously branching zoarium; branches flat, maximum width $10 \mathrm{~mm}, 4 \mathrm{~mm}$ thick; surface with maculae, most of which are depressed centrally and comprised of relatively large zooecia often with clusters of irregular-shaped mesopores.

\section{TANGENTIAL SECTION}

Zooecia angular to subangular, 8 to 10 in $2 \mathrm{~mm}$ in intermonticular areas (Table 7); line of demarcation well defined in some walls, otherwise a clear central area represents fused walls of contiguous zooecia 0.01 to $0.15 \mathrm{~mm}$ wide, concentrically laminated. Mesopores few in intermacular areas (Table 7), in maculae scattered or in central clusters. Acanthopores relatively few (Table 7), never inflecting zooecial void; each with concentrically laminated walls and clear central core. Diameter of zooecial aperture in maculae 0.22 to $0.26 \mathrm{~mm}$ (Table 7), in intermonticular areas 0.15 to $0.20 \mathrm{~mm}$.

\section{LONGITUDINAL SECTION}

Zooecia proceeding to surface in a gentle curve, intersecting it almost at right angles. Long endozone composed of several colonial rejuvenations (each approximately $1.5 \mathrm{~mm}$ long); walls in each successive growth thin at first, then crenulated and slightly thickened. Diaphragms rare and widely spaced. Exozone shallow $(0.05 \mathrm{~mm}$ in length); exozonal walls thicken materially and become moniliform, with wall laminae diverging at moderate angle from central core and passing into the diaphragms (usually two per zooecium). Mesopores few and slightly beadlike. Short 

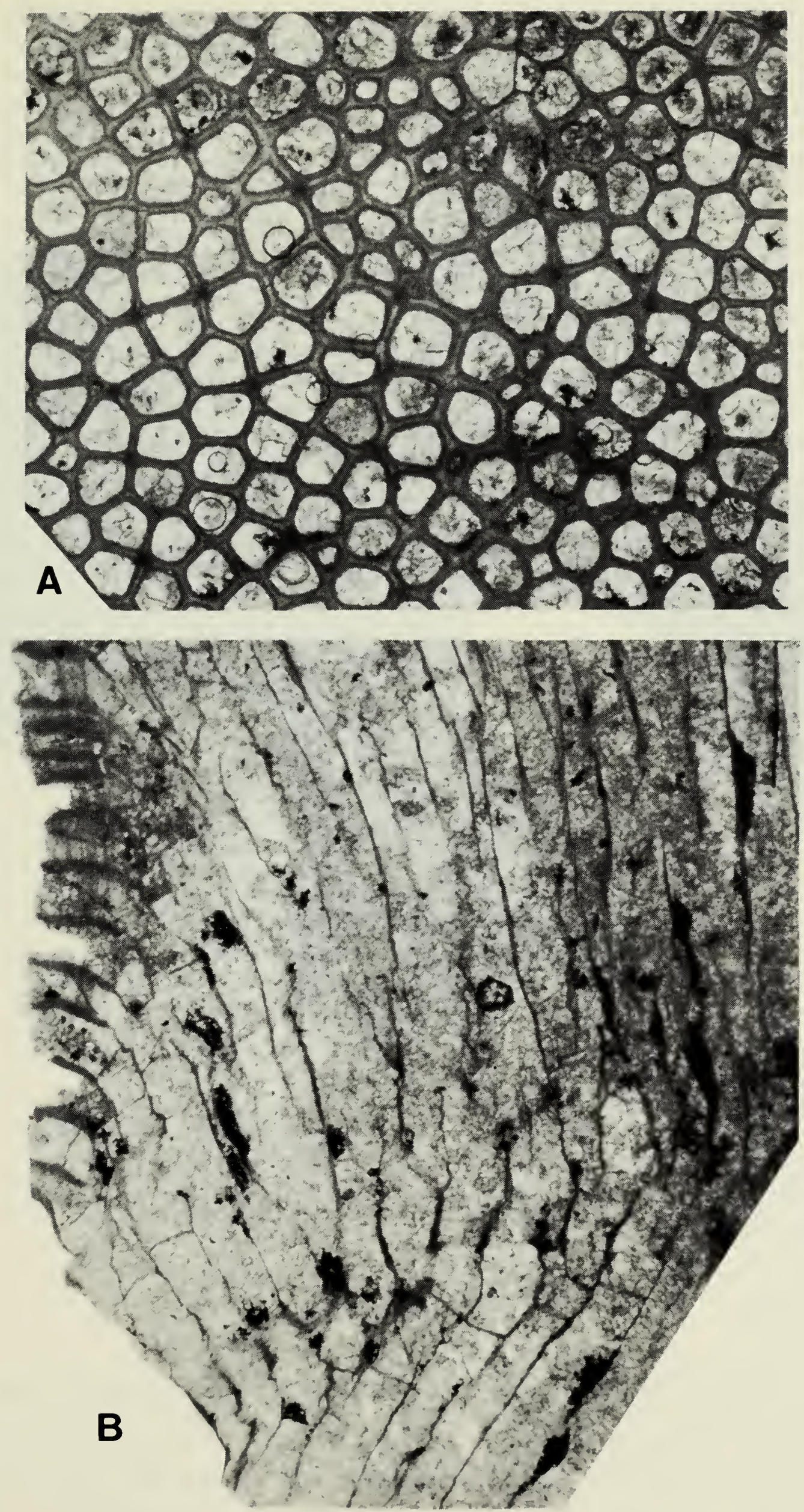

Fig. 9 A-B Stigmatella ramosa Fritz, holotype, ROM 1317HR.

A Tangential section, $\times 30$

B Longitudinal section, $\times 30$ 


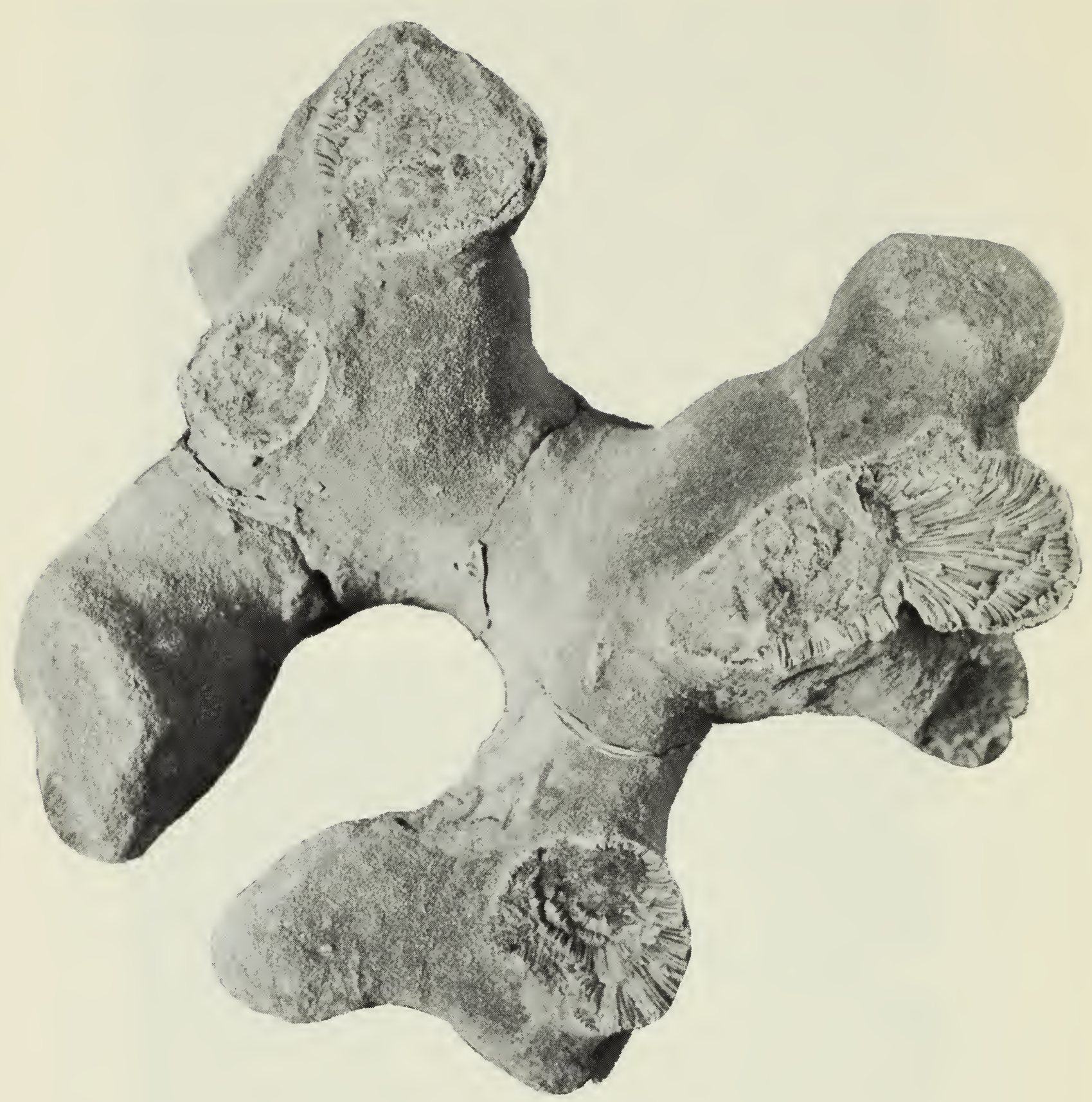

Fig. 10 Stigmatella intermedia Fritz, holotype, ROM 1276HR.

acanthopores, with clear central core, may be traced from their origin in zooecial walls to their spiniform termination.

\section{Remarks}

The medium-sized flattened branches with depressed maculae distinguish this species from any other in the Meaford fauna. It is here compared statistically with the type of Stigmatella vulgaris (ROM 1091HR), with which species S. ramosa was originally described as a subspecies. Table 7 indicates that the two species differ significantly in the number of zooecia in $2 \mathrm{~mm}$ in intermonticular area, number of entire acanthopores in $1 \mathrm{~mm}^{2}$ in intermonticular area, and the maximum apertural diameter of zooecia in monticule areas. 


\section{Type}

Holotype: ROM 1317HR, Dundas Formation, Humber Member, Workman's Creek, Ontario.

\section{Acknowledgements}

My sincere thanks to members of the Department of Invertebrate Palaeontology, ROM: Janet Waddington, for calculating the Mann-Whitney U Statistics; David Rudkin and Peter Fenton for restoring certain thin sections, preparation of new sections, and assembling the plates; Joan Burke for her proficient professional assistance during the preparation of the Contribution and for typing the manuscript.

My thanks also to Richard Boardman, Curator of Invertebrate Paleontology, National Museum of Natural History (USNM), for the loan of figured specimens of Stigmatella crenulata examined during the current research.

The photographs were taken by Brian O'Donovan, Department of Geology, University of Toronto. 


\section{Literature Cited}

BASSLER, R.S.

1903 The structural features of the bryozoan genus Homotrypa, with descriptions of species from the Cincinnatian Group. Proceedings of the United States National Museum 26:565-591.

BOARDMAN, R.S.and J. UTGAARD

1966 A revision of the Ordovician bryozoan genera Monticulipora, Peronopora, Heterotrypa, and Dekayia. Journal of Paleontology 40: 1082-1108.

CALEY, J.F.

1936 The Ordovician of Manitoulin Island, Ontario. Geological Survey of Canada, Memoir 202:21-91.

CUMINGS, E.R. and J.J. GALLOWAY

1913 The stratigraphy and paleontology of the Tanner's Creek section of the Cincinnati series of Indiana. Indiana Department of Geology and Natural Resources, 37th Annual Report, 1912:353-479.

DYER, W.S.

1925 The stratigraphy and paleontology of Toronto and vicinity. Part V. The paleontology of the Credit River section. Annual Report of the Ontario Department of Mines, 1923, $32(7): 47-88$.

FRITZ, M.A.

1926 The stratigraphy and palaeontology of the Workman's Creek section of the Cincinnatian series of Ontario. Transactions of the Royal Society of Canada, Series 3, 20(4): 77-108.

1973 Redescription of type specimens of bryozoan Stigmatella from the Upper Ordovician of the Toronto region, Ontario. Royal Ontario Museum, Life Sciences Contributions 87: 1-31.

1977 Redescription of type specimens of species of the bryozoan genera Atactoporella, Homotrypa, and Homotrypella, from the Upper Ordovician rocks of the Credit River Valley, Ontario, Canada. Royal Ontario Museum, Life Sciences Contributions 111:1-24.

JAMES, U.P.

1881 Descriptions of Cincinnatian and other Paleozoic fossils. The Paleontologist 5:33-44.

LIBERTY, B.A.

1969 Palaeozoic geology of the Lake Simcoe area, Ontario. Geological Survey of Canada, Memoir 355:1-201.

MILNE-EDWARDS, $\mathrm{H}$. and J. HAIME

1851 Monographie des polypiers fossiles des terrains palaeozoiques. Archives du Muséum National d'Histoire Naturelle (Paris) 5:1-502.

NICHOLSON, H.A.

1881 On the structure and affinities of the genus Monticulipora and its sub-genera, with critical descriptions of illustrative species. Edinburgh, W. Blackwood. 240 pp.

PARKS, W.A

1925a The stratigraphy and paleontology of Toronto and vicinity. Part V1. Stratigraphy. Annual Report of the Ontario Department of Mines, 1923, 32(7):89-116.

1925b The stratigraphy and paleontology of Toronto and vicinity. Addenda et corrigenda (Parts I to IV). Annual Report of the Ontario Department of Mines, 1923, 32(7):35-38

PARKS, W.A. and W.S. DYER

1922 The stratigraphy and paleontology of Toronto and vicinity. Part II. The Molluscoidea. Annual Report of the Ontario Department of Mines, 1921, 30(7):1-59. 
SIEGEL, S

1956 Nonparametric statistics for the behavioral sciences. New York, McGraw-Hill. 312 pp.

ULRICH, E.O.

1882 American Palaeozoic Bryozoa. Journal of the Cincinnati Society of Natural History 5:121-175.

1890 Palaeozoic Bryozoa. Geological Survey of Illinois 8:285-677.

ULRICH, E.O. and R.S. BASSLER

1904 A revision of the Paleozoic Bryozoa. Part II. On the genera and species of Trepostomata. Smithsonian Miscellaneous Collections 47:15-55. 


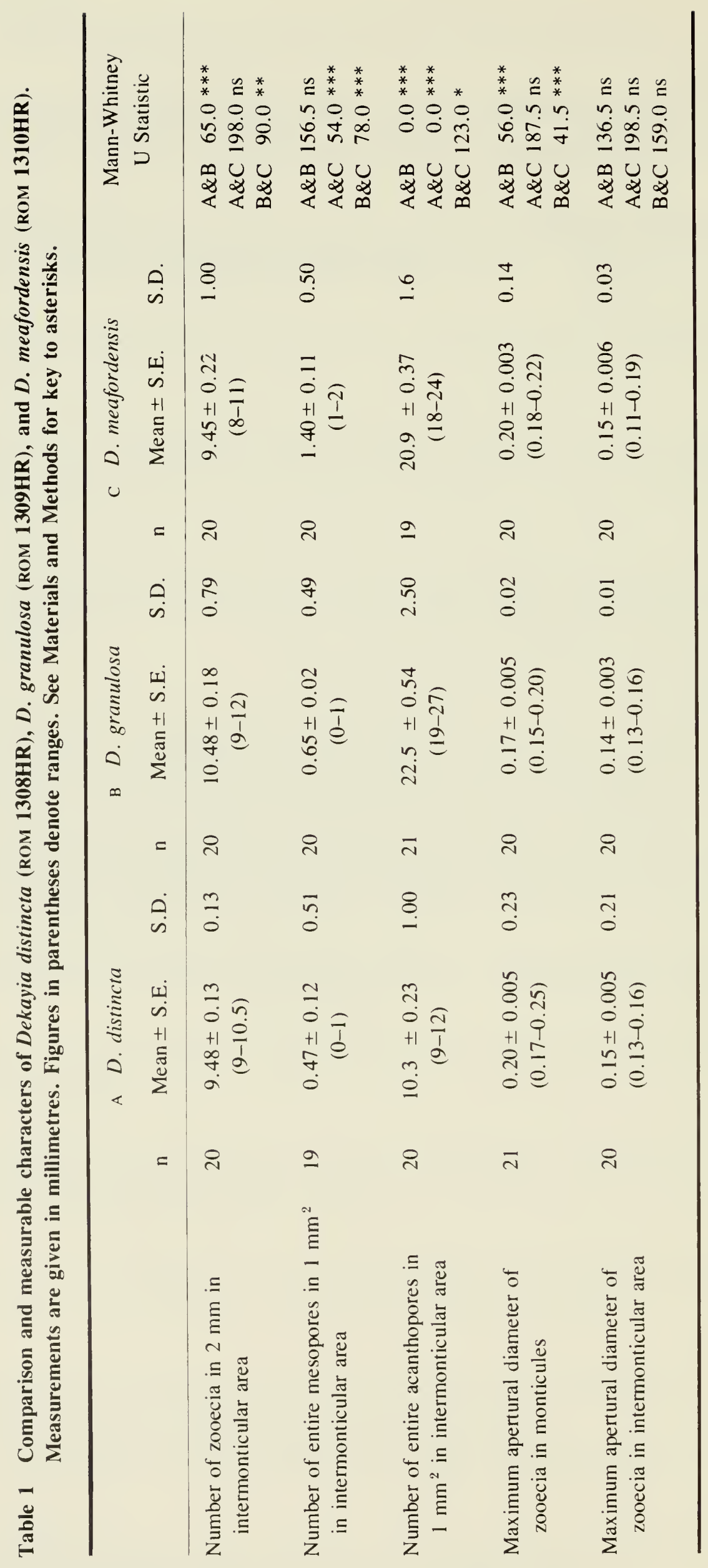




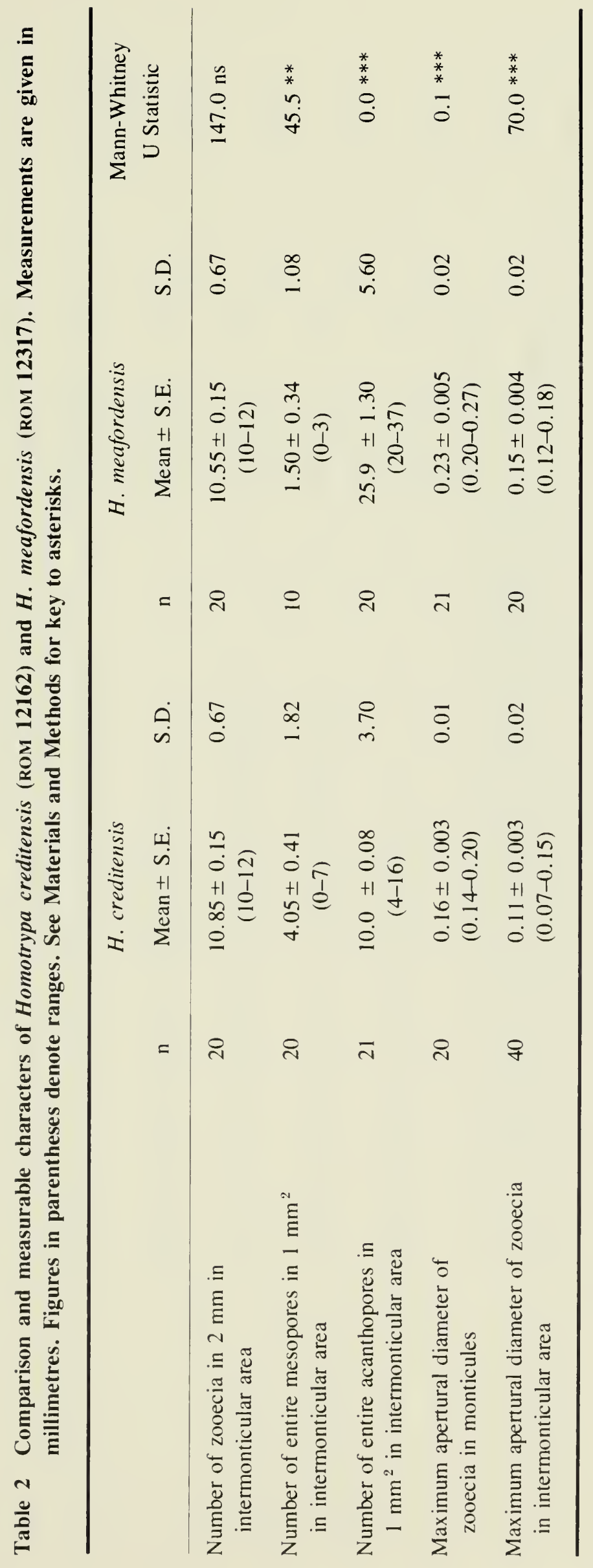




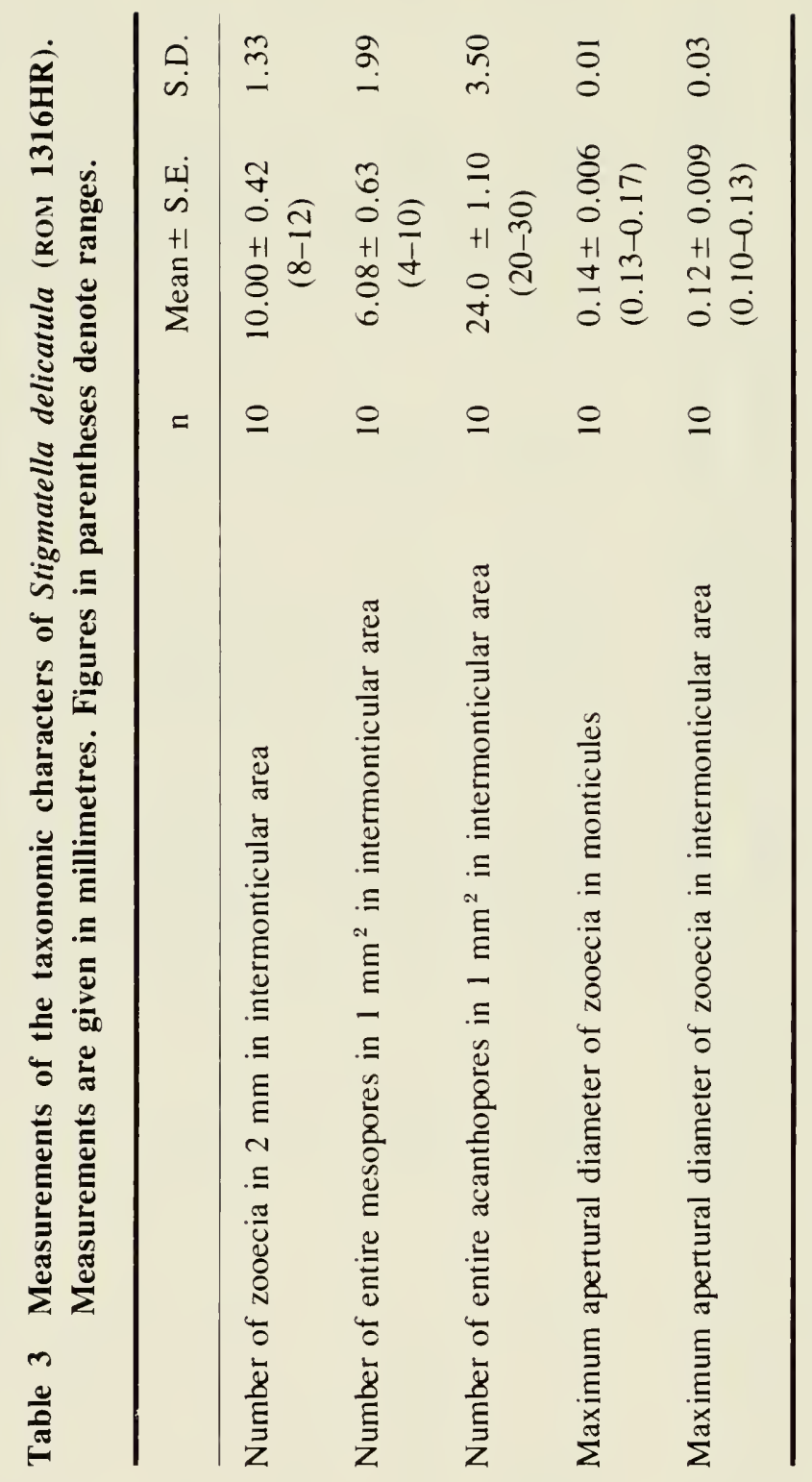




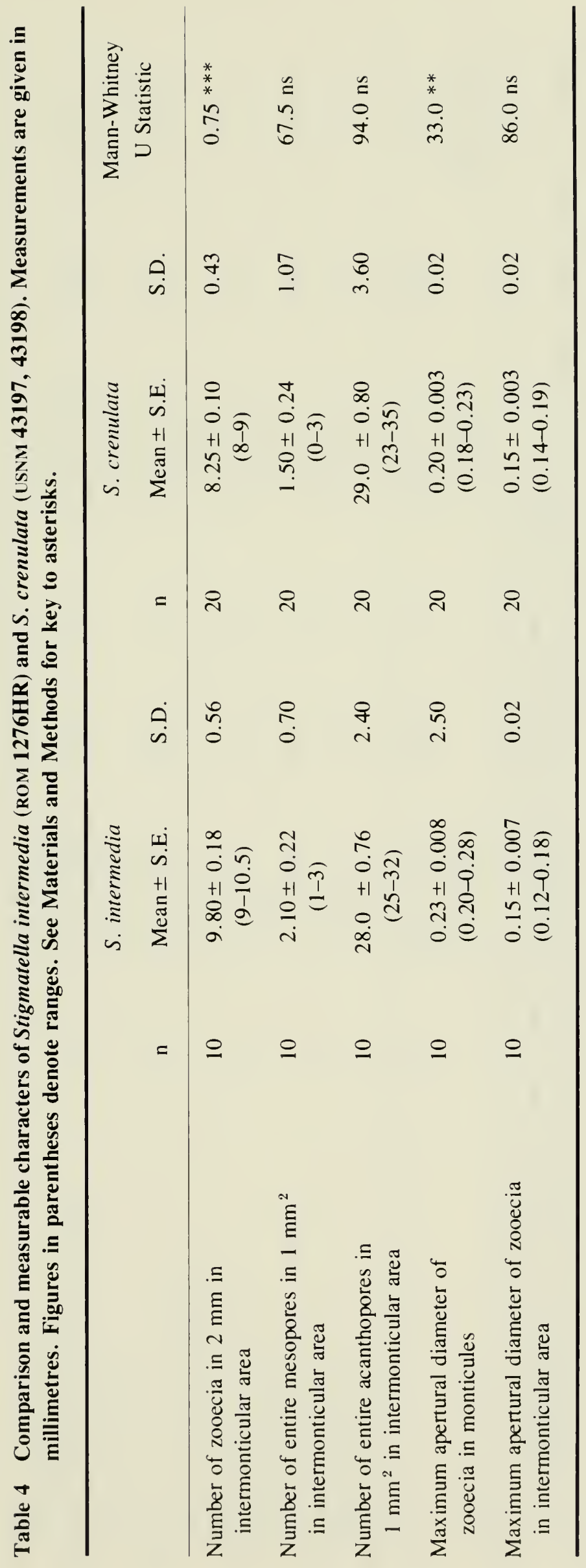




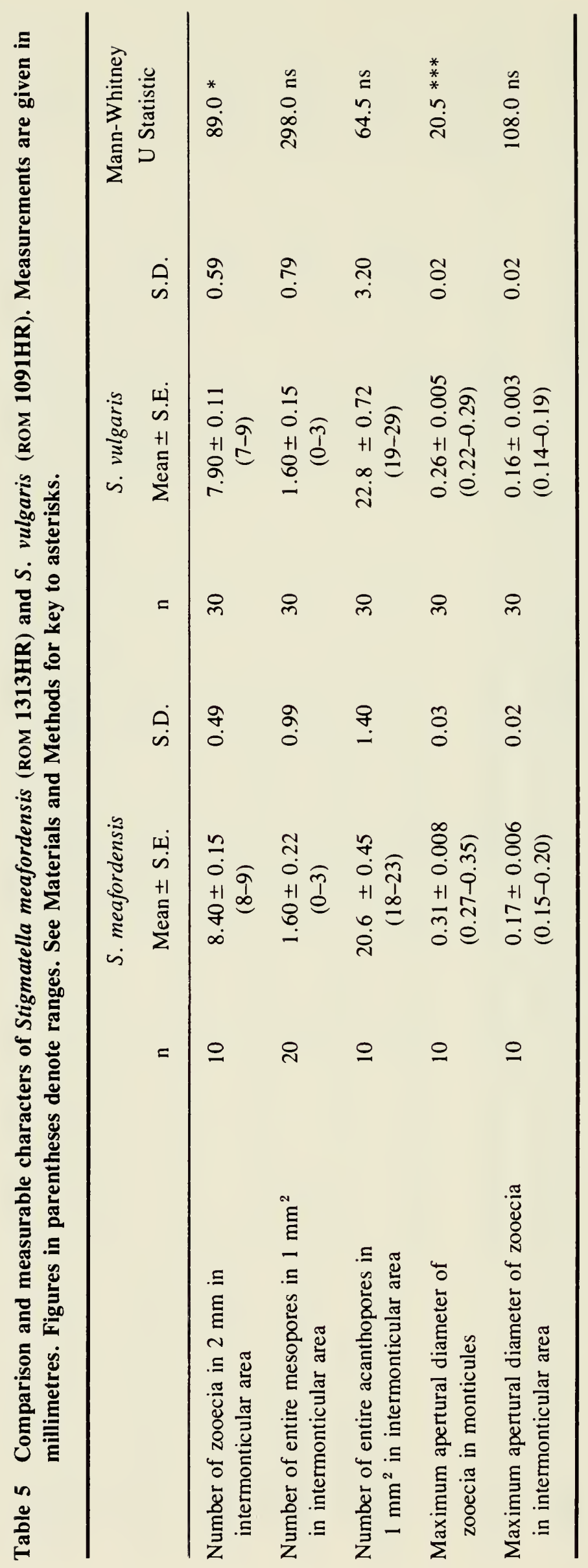




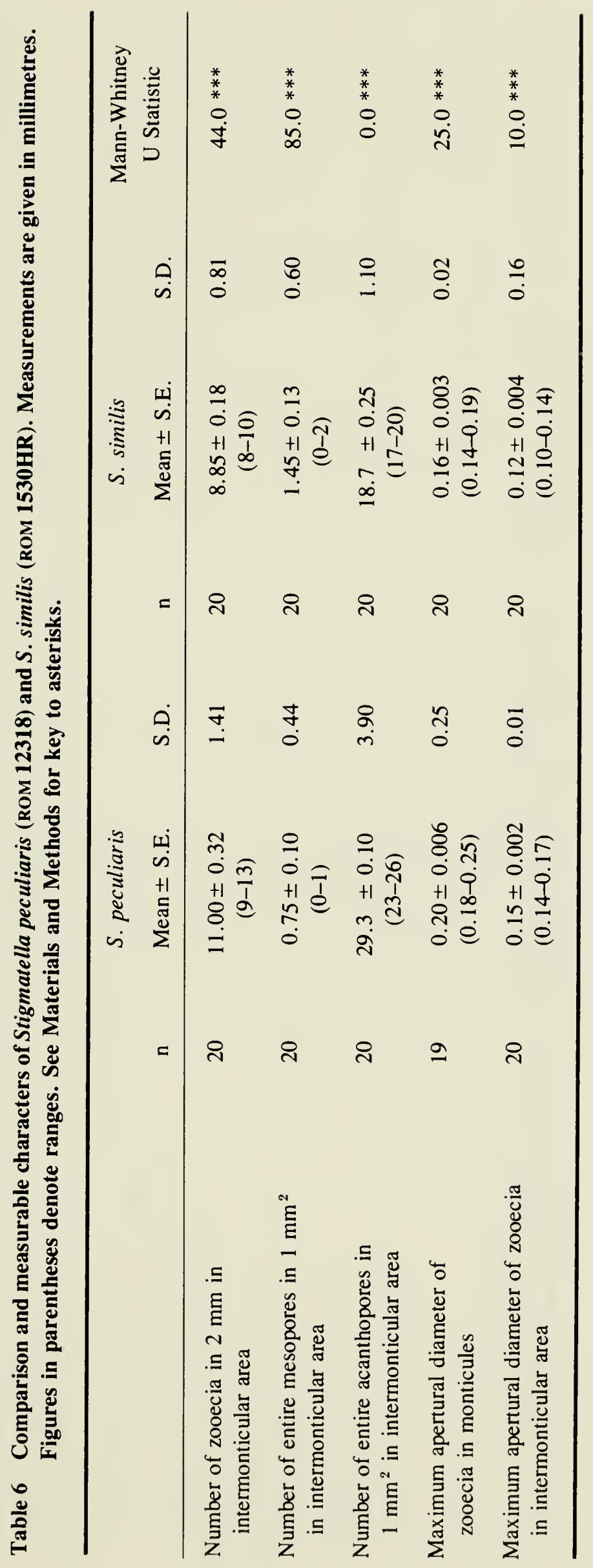




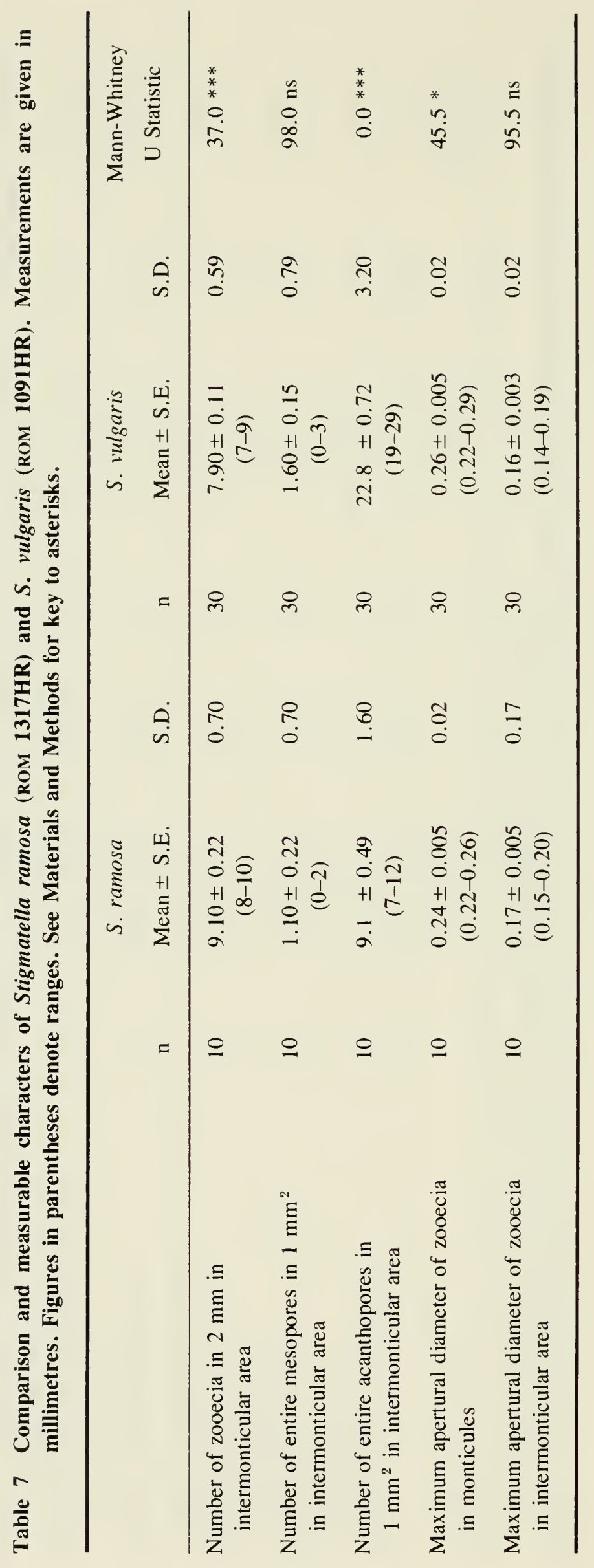





ISBN 0-88854-285-2

ISSN 0384-8159 